\title{
Anthropogenically forced decadal change of South Asian summer monsoon across the mid-1990s
}

Article

Accepted Version

Luo, F., Dong, B., Tian, F. and Li, S. (2019) Anthropogenically forced decadal change of South Asian summer monsoon across the mid-1990s. JGR Atmospheres, 124 (2). pp. 806824. ISSN 2169-8996 doi:

https://doi.org/10.1029/2018JD029195 Available at https://centaur.reading.ac.uk/81193/

It is advisable to refer to the publisher's version if you intend to cite from the work. See Guidance on citing.

To link to this article DOI: http://dx.doi.org/10.1029/2018JD029195

Publisher: American Geophysical Union

All outputs in CentAUR are protected by Intellectual Property Rights law, including copyright law. Copyright and IPR is retained by the creators or other copyright holders. Terms and conditions for use of this material are defined in the End User Agreement.

www.reading.ac.uk/centaur 
Central Archive at the University of Reading

Reading's research outputs online 


\title{
Anthropogenically forced decadal change of South Asian summer
} monsoon across the mid-1990s

\author{
Feifei Luo ${ }^{1}$, Buwen Dong ${ }^{2}$, Fangxing Tian ${ }^{2}$, and Shuanglin $\mathrm{Li}^{1,3}$
}

1. Nansen-Zhu International Research Centre and Climate Change Research Center, Institute of Atmospheric Physics, Chinese Academy of Sciences, Beijing, China

2. National Centre for Atmospheric Science, Department of Meteorology, University of Reading, Reading, UK

3. Department of Atmospheric Science, China University of Geoscience, Wuhan, China
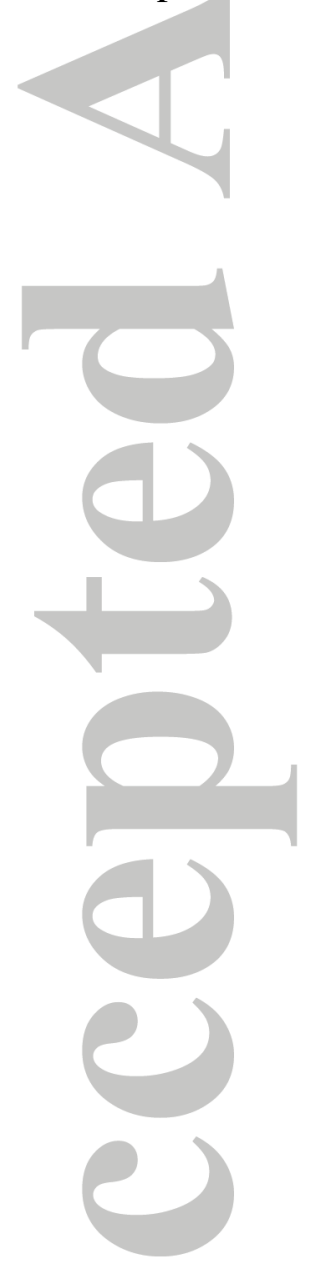

This article has been accepted for publication and undergone full peer review but has not been through the copyediting, typesetting, pagination and proofreading process which may lead to differences between this version and the Version of Record. Please cite this article as doi: 10.1029/2018JD029195 


\begin{abstract}
Analysis of observations indicates that there was a significant decadal change in summer (June-August) mean rainfall over South Asia and Southeast Asia across the mid-1990s, which is characterized by less rainfall over central-northern India and northern Indo-China Peninsula. This study investigates impacts of anthropogenic forcing on the observed decadal change across the mid-1990s. A set of experiments using the coupled atmosphere-ocean-mixed-layer model MetUM-GOML2 has been performed to quantify the relative roles of changes in anthropogenic greenhouse gases (GHG) and anthropogenic aerosols (AA). Results indicate a dominant role of anthropogenic changes in the observed decadal changes. Separately, the changes in GHG forcing play an important role in the reduction of rainfall over central-northern India through the changes of atmospheric circulation (i.e. the local Hadley circulation and the Walker circulation), with additional contribution from changes in AA forcing. The changes in AA forcing dominate the reduction of rainfall over northern Indo-China Peninsula due to high-pressure anomalies over northern South Asia and the western subtropical Pacific. These high-pressure anomalies are induced by the surface cooling mainly via aerosol-radiation interaction that decreases downward clear sky shortwave radiation over South Asia during summer, and aerosol-radiation interaction and aerosol-cloud interaction that decrease downward shortwave radiation over the western subtropical Pacific during pre-summer seasons.
\end{abstract}

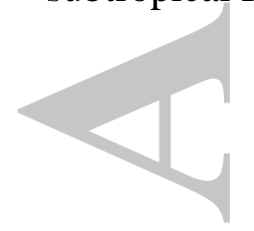




\section{Introduction}

The South Asian summer monsoon (SASM) is the most important climatic feature to society and ecosystems of South and Southeast Asia, because of the tremendous effect of abundant rainfall on agriculture, hydroelectric generation, industrial development and so on [e.g., Webster et al., 1998; Goswami et al., 1999; Ramesh and Goswami, 2007]. On the other hand, the SASM also plays an important role for the global-scale atmospheric circulation, which has a close relationship with the Hadley circulation and the Walker circulation [e.g., Goswami et al., 1999; Kumar et al., 1999; Krishnamurthy and Goswami, 2000], and can affect the downstream area via a Rossby wave train [Ding and Wang, 2005]. Hence, understanding the characteristics and mechanisms of the SASM variability at different timescales is imperative and challenging to society and climate science [Ding, 2007, 2009; Turner and Annamalai, 2012]. Recently, Choi et al. [2017] proposed that the SASM underwent a decadal variation across the mid-1990s, characterized by reductions of monsoon circulation and rainfall over Indian subcontinent and the Indo-China peninsula. However, few studies have scrutinized the possible causes of this decadal change.

On the decadal-to-multidecadal timescales, the variation of the SASM has been attributed to internal decadal variability [i.e. the Pacific Decadal Oscillation (PDO), the Atlantic Multidecadal Oscillation (AMO)] [e.g., Zhang and Delworth, 2005; Goswami et al., 2006; Li et al., 2008; Krishnamurthy and Krishnamurthy, 2014] and external forcing [i.e. the greenhouse gas (GHG), anthropogenic aerosols (AA)] [e.g., Ueda et al., 2006; Lau et al., 2006; Chung et al., 
2006; Sun and Ding, 2011; Bollasina et al., 2011; Cui et al., 2014; Shi et al., 2014; Guo et al., 2015; Krishnan et al., 2016; Li and Mahmood, 2017]. Since the mid-1990s, the potential drivers have changed. The PDO began to turn into a negative phase, and the AMO entered a positive phase [e.g., Kosaka and Xie, 2013; Dai et al., 2015; Steinman et al., 2015]. There have been significant increases in anthropogenic GHG concentrations in the period of 1996-2011 relative to the period of $1964-1993$ (11\% increase in $\mathrm{CO}_{2}, 18 \%$ increase in $\mathrm{CH}_{4}$, and $6 \%$ increase in $\mathrm{N}_{2} \mathrm{O}$ ), and significant changes in AA precursor emissions with Asian sulphur dioxide emissions increased while European and North American emissions decreased [Lamarque et al., 2010; see figure 3b in Dong et al., 2017a]. For the internal decadal variability, some studies have indicated that the change in the PDO or AMO across the mid-1990s cannot explain the decadal change of SASM [Sankar et al., 2016; Luo et al., 2018], because a negative PDO or a positive AMO phase should correspond to a wet SASM phase [e.g., Goswami et al., 2006; Krishnamurthy and Krishnamurthy, 2014]. Hence, our major aim is the impacts of anthropogenic forcing on the SASM decadal change in this study.

For the GHG effect, the SASM rainfall increases due to more precipitable water in the atmosphere related to oceanic warming and an enhanced land-sea thermal contrast (i.e., warm-ocean-warmer-land) [Sun and Ding, 2011; Lau and Kim, 2017]. In addition, GHG forcing leads to the weakening of tropical atmospheric circulation because of the energy and mass balance, which tends to suppress the monsoon circulation and rainfall [Ueda et al., 2006; Vecchi et al., 2006; Turner and Annamalai, 2012]. However, most of the previous studies have 
focused on either the projected simulations under different scenarios or $2 \times \mathrm{CO}_{2}$ experiments.

The effects of AA on the surface and atmospheric temperature include the aerosol-radiation interaction by scattering and absorbing the solar radiation directly and the aerosol-cloud interaction by altering the radiative properties of clouds [e.g., Wang et al., 2016; Li et al., 2016; Li et al., 2017]. In addition, the dynamic effect due to the spatial heterogeneity of AA emissions concentrated over the northern hemisphere induces the southward shift of the intertropical convergence zone (ITCZ) because of the change in horizontal temperature gradients [Rotstayn and Lohmann, 2002; Ming and Ramaswamy, 2011]. Lau and Kim [2017] indicated that the cooling effect caused by increased AA emissions over South Asia could offset a large extent of the rainfall increase due to GHG warming. Bollasina et al. [2011] has proposed that the weakening of the SASM is a robust result of a slowdown of the tropical meridional overturning circulation, which compensates for the aerosol-induced energy imbalance between the Northern and Southern Hemispheres. Guo et al. [2015] further suggested that indirect aerosol effects acting on very local aerosol emission regions also play a role in declining monsoon rainfall. Hence, AA forcing has been considered as a major contributor to the drying trend during the second half of the $20^{\text {th }}$ century.

It should be noted that most of previous studies focus on the anthropogenically forced SASM in the Indian subcontinent. Here, besides the Indian subcontinent, we have investigated the anthropogenic impacts on the Indo-China peninsula, considering the variations of SASM in the two areas are more or less independent [Wang and Fan, 1999; Li 
and Zeng, 2002; Zhang et al., 2010; Misra and DiNapoli, 2014; Tsai et al., 2015]. In this studies, we aim to address the following two issues: (1) To explore whether or not anthropogenic forcing plays a role in leading to the decadal change of the SASM across the mid-1990s. (2) To quantify the relative roles of changes in GHG and AA forcings in shaping the recent decadal change, and to understand the physical processes involved.

Up to now, most of the attribution studies are based on Atmospheric General Circulation models (AGCMs) and Coupled General Circulation Models (CGCMs), i.e. experiments that use constant emissions to force the models and reach equilibrium after a long integration [e.g., Bollasina et al., 2011; Wang et al., 2013; Mahmood and Li, 2014; Dong et al., 2016; Lau and Kim, 2017]. However, a limitation of AGCMs is the lack of air-sea coupling processes. The air-sea interaction is of importance in modulating the Asian monsoon [Ganguly et al., 2012; Song and Zhou 2014a, 2014b; Zhou et al., 2015; Xu and Xie, 2015; Samset et al., 2016; Dong et al., 2017; Wang et al., 2017]. Although CGCMs include full ocean dynamics, CGCMs still exhibit significant biases in the mean state. For example, many CGCMs have a large cold equatorial sea surface temperature (SST) bias in Pacific [Vanniere et al., 2012; Wang et al., 2014]. Hence, a coupled atmosphere ocean mixed-layer model provides an alternative tool for attribution studies [Dong et al., 2017]. The coupled atmosphere ocean mixed-layer model considers ocean thermodynamics that causes the majority of subseasonal tropical upper ocean variability [e.g., Waliser et al., 2004]. Replacing the 3D ocean GCM with an ocean mixed-layer model would reduce the cost of the experiments, and have a 
smaller SST bias due to a prescribed flux correction, whilst also retaining intraseasonal variability and coupling between the atmosphere and the ocean. Therefore, this study is based on a set of experiments using a near-globally coupled atmosphere-ocean-mixed-layer model, MetUM-GOML2 [Klingaman et al., 2011; Hirons et al., 2015].

The paper is organized as follows: Section 2 describes the observed changes in rainfall across the mid-1990s; section 3 describes the model, experiments and simulated climatology; section 4 examines model responses to changes in anthropogenic forcing; Section 5 investigates the physical processes involved in these responses of rainfall over South and Southeast Asia to changes in GHG and AA forcings, respectively. Finally, a summary is provided in Section 6.

\section{Observed decadal changes of the SASM}

\subsection{Observational data sets}

Considering uncertainties of monthly global land precipitation datasets, we used three observation/reanalysis datasets for 1964-2011, including the Climate Research Unit Precip 3.2 dataset (CRU) on a $0.5^{\circ} \times 0.5^{\circ}$ grid [Mitchell and Jones, 2005], the University of Delaware monthly precipitation dataset (UDEL) on a $0.5^{\circ} \times 0.5^{\circ}$ grid [Willmott and Matsuura, 2001], and the NOAA's Precipitation Reconstruction over Land (PREC/L) on a $0.5^{\circ} \times 0.5^{\circ}$ grid $[$ Chen et al., 2002]. The horizontal wind components, U and V, are from the NCEP/NCAR reanalysis version 1.0 on a $2.5^{\circ} \times 2.5^{\circ}$ grid [Kalnay et al., 1996]. Observed sea level pressure (SLP) data are obtained from the Hadley Centre's monthly historical mean SLP data set (HadSLP2r) in a 
horizontal resolution of $5^{\circ} \times 5^{\circ}$ [Allan and Ansell, 2006]. The monthly sea surface temperature (SST) is from the Met Office Hadley Centre's monthly SST records (HadISST) [Rayner et al., 2003], gridded to $1.0^{\circ}$ latitude by $1.0^{\circ}$ longitude.

\subsection{Observed changes}

To show the decadal changes of the SASM in the Indian subcontinent (ISM) and the Indo-China peninsula (SEASM) in observations, the rainfall indices over ISM and SEASM regions, hereafter named as ISR (Indian Summer Rainfall) and SEASR (Southeast Asian Summer Rainfall) are defined as the summer (June-August) averaged land rainfalls over central-northern India $\left(20^{\circ} \mathrm{N}-30^{\circ} \mathrm{N}, 75^{\circ} \mathrm{E}-87^{\circ} \mathrm{E}\right.$; see the black box in Figure 2) and over northern Indo-China Peninsula $\left(17^{\circ} \mathrm{N}-28^{\circ} \mathrm{N}, 90^{\circ} \mathrm{E}-100^{\circ} \mathrm{E}\right.$; see the black box in Figure 2$)$, respectively. Figure 1 shows time series of the anomalies for the two indices relative to the climatology of 1964-2011. It shows that more precipitation of the ISR and SEASR occurred during the early period (EP, 1964-1981) than the present day (PD, 1994-2011). To avoid possible impacts of volcanic eruptions, two time-periods selected to characterize the decadal changes across the mid-1990s are slightly different from those selected in Choi et al. [2017]. Quantitatively, the ISR decreased by around $0.23 \sim 1.22 \mathrm{~mm} /$ day, and SEASR decreased by around $0.6 \sim 1.25 \mathrm{~mm} /$ day (Figure 1) from the EP to PD. The decadal changes of the ISR and SEASR are statistically significant, which are greater than the $90 \%$ confidence level, except for the change of ISR in PREC/L (Figure 1). This decadal weakening of ISR and SEASR is consistent with the previous study [Choi et al., 2017], which used the Webster-Yang index 
[Webster and Yang, 1992].

The spatial distributions of changes in summer precipitation between the PD and EP show a tripole pattern with a significant reduction over northern India and northern Indo-China Peninsula, an increase over central area around $15^{\circ}-20^{\circ} \mathrm{N}$ and a decrease over southern area around $10^{\circ} \mathrm{N}$ (Figure $2 \mathrm{a}-\mathrm{c}$ ). This work focuses on the northern region with largest variations. As illustrated in figure $2 \mathrm{~d}$, the decreased ISR is likely to be associated with high-pressure anomalies over northern India associated with anomalous easterlies across the Indian Peninsula. The anomalous easterly wind over northern Indo-China Peninsula indicates weaker westerly wind across the region, which is associated with the decreased SEASR.

To understand the roles of anthropogenic forcing in influencing the decadal changes of the observed monsoonal rainfall over two regions across the mid-1990s, and to elucidate the potential physical mechanisms involved, we utilized a coupled atmosphere-ocean-mixed-layer model and conducted a set of experiments with both GHG and AA forcing, only GHG forcing, and only AA forcing.

\section{Model and experiments}

\subsection{MetUM-GOML2 and Experiments}

The model used here is a coupled atmosphere-ocean-mixed-layer model named MetUM-COML2. The atmospheric component is the Met Office Unified Model (MetUM) at the fixed scientific configuration Global Atmosphere 6.0 (GA6.0) with a horizontal resolution 
of $1.875^{\circ}$ longitude and $1.25^{\circ}$ latitude (N96), and a total of 85 vertical levels [Walters et al., 2017]. The model includes an interactive tropospheric chemistry scheme and the following species of tropospheric aerosols: ammonium sulphate, mineral dust, sea salt, fossil fuel black carbon, fossil fuel organic carbon, biomass burning aerosols, and secondary organic (biogenic) aerosols. Both aerosol-radiation and aerosol-cloud interactions are considered [Walters et al., 2011]. The aerosol-radiation interaction due to scattering and absorption of radiation by all aerosol species is represented in the model. The semi-direct effect whereby aerosol absorption tends to change cloud formation by warming the aerosol layer is included [Walters et al., 2011]. The parameterization of the indirect effects is described in detail by Jones et al. [2011]. The parametrization of cloud droplets is described in Edwards and Slingo [1996] using the method of "thick averaging". Padé fits are used for the variation with effective radius, which is computed from the number of cloud droplets [Walters et al., 2011]. Data sets required by the tropospheric aerosol scheme in the model are emissions of Sulphur dioxide $\left(\mathrm{SO}_{2}\right)$, land-based dimethyl sulphide (DMS), ammonia $\left(\mathrm{NH}_{3}\right)$, and primary black and organic carbon aerosols from fossil fuel combustion and biomass burning [Bellouin et al., 2013]. The oceanic component is a Multi-Column K Profile Parameterization (MC-KPP) mixed-layer ocean model with the same horizontal resolution of the MetUM with 100 vertical levels and a depth of $1000 \mathrm{~m}$. Vertical mixing in MC-KPP is parameterized using the KPP scheme of Large et al. [1994]. Since the mixed-layer model (MC-KPP) does not include ocean dynamics, seasonally varying 3D flux corrections are applied to both ocean temperature and salinity. The 
climatological seasonally varying 3D temperature and salinity flux corrections are prescribed to represent the mean ocean advection and account for biases in atmospheric surface fluxes. The Ocean Atmosphere Sea Ice Soil (OASIS) [Valcke et al., 2003] is used to couple the atmospheric and oceanic components every three hours.

In this study, five time-slice experiments were performed: A relaxation experiment (R0) in which the 3D temperature and salinity of the ocean are relaxed to a present day (PD, 1994-2011) climatology with PD GHG and AA forcing [Lamarque et al., 2010, 2011] is used to diagnose the 3D ocean temperature and salinity corrections. Then four experiments were performed with prescribed same 3D ocean temperature and salinity corrections, but with different anthropogenic forcings; an early period (EP, 1964-1981) experiment forced by EP GHG and AA forcings; PDGA experiment forced by the PD GHG and AA forcings; PDG and PDA experiments forced by the PD GHG forcing with EP AA and by PD AA forcing with EP GHG, respectively. All experiments are run for 60 years and use the climatological PD sea ice extent from HadISST [Rayner et al., 2003]. The last 55 years of each experiment are used for analysis.

The details of the experiments are listed in Table 1.

The response to a particular forcing is estimated by the mean difference between a pair of experiments that include and exclude that forcing. The difference between PDGA and EP experiment (PDGA - EP) denotes the combined effect of changes in both GHG and AA (hereafter All Forcing). The difference between PDG and EP (PDG - EP) indicates the impact of change in GHG (hereafter GHG forcing), and the difference between PDA and EP (PDA - 
$\mathrm{EP}$ ) is the impact of change in AA emission (hereafter AA forcing). For the GHG concentration, there is $14 \%$ increase in $\mathrm{CO}_{2}, 23 \%$ increase in $\mathrm{CH}_{4}$ and $7 \%$ increase in $\mathrm{N}_{2} \mathrm{O}$ for PD relative to EP. Changes in AA in the simulations consist of changes in sulfate, soot, biomass, and also other species [Bellouin et al., 2013]. However, the change in sulfate plays a dominated role in the responses to AA forcing, because it is much larger than changes in soot AOD and biomass AOD [see Figure 14 in Dong et al., 2016]. Hence, the response to AA forcing mainly reflect the effect of sulfate. Statistical significance of the mean changes in model experiments is assessed using a two tailed Student t-test.

\subsection{Climatology}

The model is evaluated by comparing the simulated climatological summer precipitation, lower tropospheric circulation and SST in the PDGA experiment with those in observations. The observed precipitation in India is characterized by more precipitation over northern India, and a maximum along the west coast of India (Figure 3a-c). The model overall reproduces these characteristics but underestimates the magnitude (Figure 3d). In Indo-China Peninsula, the precipitation concentrates in the northwestern area with $12-13 \mathrm{~mm} /$ day in observations (Figure 3a-c). The model captures the spatial pattern and magnitude of $13 \mathrm{~mm} /$ day reasonably well (Figure 3d). Then the modeled standard deviations of ISR and SEASR is comparable to that in observations (not shown). As the simulation of precipitation, the model generally reproduces the atmospheric circulation, albeit having some biases in details (Figure 3e-f). The simulated Indian Low is stronger than in observations, which may be associated with the 
overestimated westerly winds from the Arabian peninsula to India, and then leading to less precipitation over the Northern India.

Figure 4a shows the simulated summer SSTs biases relative to the HadISST, indicating the model has higher skills in simulating the SST climatology with much smaller biases (typically between $-0.5^{\circ} \mathrm{C}$ and $0.5^{\circ} \mathrm{C}$ ) than CMIP5 models (between $-2^{\circ} \mathrm{C}$ and $2^{\circ} \mathrm{C}$, Figure 1a in Wang et al., 2014). The model also generally captures the large scale patterns of observed SST differences between PD and EP, showing a relatively large warming over the North Atlantic, the tropical Indian Ocean and the tropical Pacific (Figure 4b-c). However, some discrepancies can be seen between observations and the model simulations. Note that the difference between two periods in observations includes both the internal variability and external forcing induced change, while the difference in the model simulations is only due to anthropogenic forcing.

Given that MetUM-GOML2 simulates the essential features of the climatological precipitation, lower tropospheric circulation and SST reasonably well, it is an appropriate tool to investigate the response of regional precipitation to changes in different anthropogenic forcings.

\section{Simulated changes in response to different forcings}

Figure 5 displays the spatial patterns of changes in summer precipitation and lower tropospheric circulation in response to changes of All forcing (PDGA - EP). Compared with observations (Figure 2a-c), the model generally reproduces the decreased precipitation over the Northern India, with the ISR decreased by $0.19 \pm 0.23 \mathrm{~mm} /$ day (Figure $5 \mathrm{a}$ ). In the Northwestern Indo-China Peninsula, the simulated precipitation change exhibits a dipolar pattern with an 
increase to the north and a decrease to the south (Figure 5a). However, the increased precipitation, which may be related to a localized circulation anomaly, cannot be found in observations (Figure 2a-c). However, the model still captures the decreased precipitation in most of the area. we therefore focus on this precipitation change in such area $\left(17^{\circ} \mathrm{N}-25^{\circ} \mathrm{N}\right.$, $90^{\circ} \mathrm{E}-100^{\circ} \mathrm{E}$ ), with the area-averaged precipitation decreased by $1.26 \pm 0.3 \mathrm{~mm} / \mathrm{day}$.

In terms of atmospheric circulation, the pronounced features in SLP in response to All forcing are the two anticyclonic circulations over the Northern India and the Western North Pacific, which corresponds to those in observations (Figure $2 \mathrm{~d}$ and $5 \mathrm{~b}$ ). These changes not only suppress localized convection but also lead to anomalous easterly wind to weaken the climatological westerly across India and the Bay of Bengal (Figure 5b). However, the simulated changes in horizontal wind cannot reproduce anomalous northeasterly wind over the Northern Indo-China peninsula and central China in observations (Figure $2 \mathrm{~d}$ and $5 \mathrm{~b}$ ), which is due to that the simulation fails to capture an increase in SLP around $\left(45^{\circ} \mathrm{N}, 100^{\circ} \mathrm{E}\right)$ in observations (see Figure 1b in Tian et al., 2018). This SLP change is more likely to be associated with atmospheric internal variability such as the Silk Road Pattern [Hong et al., 2017]. Hence, it should be understandable for such differences between the simulation and observations. The similarities over South and Southeast Asia and western subtropical Pacific between the simulation and observations suggest that the anthropogenic forcing could contribute to the decadal changes of the ISR and SEASR across the mid-1990s.

The spatial patterns of changes in summer precipitation in responses to anthropogenic 
GHG forcing and AA forcing are shown in Figure 6a and 6b. GHG forcing appears to play an important role in ALL forcing experiment (Figure 6a and 5a) over Northern India. The impact of AA forcing mainly results in the changes over the Indo-China Peninsula (Figure $6 \mathrm{~b}$ and 5a). The area-averaged precipitation for the ISR and SEASR is calculated to quantify the relative roles of GHG forcing and AA forcing in the decadal changes over the two regions (Figure 6c). For the ISR, the changes show $-0.29 \pm 0.24 \mathrm{~mm} /$ day in GHG forcing and $-0.09 \pm 0.24 \mathrm{~mm} /$ day in AA forcing, indicating the important role of GHG forcing for the decadal change in Indian summer monsoon. For the SEASR, AA forcing plays a dominant role for the decadal change with the decreased precipitation of $1.0 \pm 0.28 \mathrm{~mm} /$ day, and GHG forcing has a relatively smaller contribution with $-0.64 \pm 0.34 \mathrm{~mm} /$ day. It's expected that the sum of the changes due to individual forcings is not exactly equal to the change due to ALL forcing [Feichter et al., 2004; Ming and Ramaswamy, 2009; Shiogama et al., 2012]. However, detailed discussion of this nonlinearity is beyond the scope of this study.

\section{Physical processes for the simulated changes in response to different forcings}

\subsection{The processes related to the decadal changes}

To investigate the specific processes contributing to the decadal changes in the model simulated responses, we compared the changes in the vertically integrated moisture transport convergence (Figure 7a-c) with the changes in precipitation (Figure 5a, 6a-b). The similar spatial patterns and the comparable area-averaged values over the ISM and SEASM areas 
indicate that the changes of precipitation are dominated by the changes of moisture transport convergence in response to changes in All forcing, GHG forcing and AA forcing (Figure 7a-c and 8).

Next, we conducted the moisture budget analysis to separate the vertically integrated moisture transport convergence into the dynamic component with only changes in circulation and thermodynamic component with only changes in specific humidity [Trenberth and Guillemot, 1995; Li et al., 2015; Li and Ting, 2016]. The decomposition shows that the dynamic effect (Figure 7d-f) is the primary factor for the spatial patterns and the magnitudes of the moisture transport convergence change (Figure 7a-c). The thermodynamic effect increases moisture transport convergence over northern India in response to GHG forcing, but decreases it over Indo-China Peninsula in response to AA forcing (Figure 7g-i). The weak responses in the thermodynamic effect due to GHG forcing may be the results of weak GHG change between EP and PD in comparison with $2 \times \mathrm{CO}_{2}$ experiments. Quantitatively, the decrease of the ISR is mainly due to the dynamic effect of GHG forcing induced changes in circulation [Vecchi and Soden, 2006; Turner and Annamalai, 2012; Chen and Zhou, 2015], while the thermodynamic effect partly offsets the decrease in precipitation due to the "rich get richer" mechanism [Chou et al., 2009] (Figure 8a). Although the effects of AA forcing lead to the decrease of the ISR, the effects are weak relative to GHG forcing (Figure 8a). For the SEASR, dynamic components of GHG and AA forcings induced changes in circulation play the main role for the change in the moisture transport convergence, but the response to AA 
forcing is more than twice the magnitude of GHG forcing induced change (Figure 8b). The thermodynamic components are relatively weak in response to GHG and AA forcing changes (Figure 8b).

Based on the analysis above, the effects of GHG forcing show that the dynamic components induce the decrease of the monsoon rainfall and the thermodynamic components lead to the increase; the effects of AA forcing give rise to the decrease in both the dynamic and thermodynamic processes. These effects of anthropogenic forcing in MetUM-COML2 are consistent with previous studies, although the dominated factor is different [e.g., Vecchi and Soden, 2006; Bollasina et al., 2011; Turner and Annamalai, 2012; Guo et al., 2015; Chen and Zhou, 2015]. However, to the decadal changes across the mid-1990s, the changes in atmospheric circulations induced by GHG and AA forcings dominate the monsoonal decadal changes. We therefore focus on addressing main physical processes involved for changes in atmospheric circulation in response to GHG and AA forcings and give rise to the decreased ISR and SEASR in the next sections.

\subsection{Changes of atmospheric circulation induced by GHG forcing}

In the lower troposphere, GHG forcing leads to northeasterly anomalies across India and high-pressure anomalies over the Indian subcontinent, northern Indian Ocean and the Maritime Continent that corresponds to a weakened monsoon circulation (Figure 9a). A humble anticyclonic circulation center located in the northeast Bay of Bengal leads to southwesterly anomalies along the north side of the center and then more rainfall over 
northern SEASM region (Figure 6a, 7b and 7e), which may be due to the flow interaction with local topography. In addition, there is a convergence center over southern Indian Ocean and anomalous westerly wind over the equatorial Pacific (Figure 9a). The former indicates a change of local Hadley circulation, and the latter is associated with a weakened Walker circulation (Figure 9b and c). The change in local Hadley circulation is characterized by a descending motion over $0^{\circ}-30^{\circ} \mathrm{N}$ and an ascending motion over $10^{\circ} \mathrm{S}-30^{\circ} \mathrm{S}$, which corresponds to the decreased rainfall in the Indian subcontinent (Figure 9b). On the other hand, the weakened Walker circulation leads to a weakened ISM through abating the easterly trade wind across the equatorial Pacific, which is related to the El Niño-like pattern over the Pacific (Figure 9d) [e.g. Webster and Yang, 1992; Turner et al., 2005; Roy et al., 2017]. Such a SST pattern is induced by the increased downward clear sky longwave radiation (LW) due to Greenhouse Effect (Figure 9e). This result is consistent with that of fully coupled models [Dong et al., 2014]. Because mixed layer depth is shallower in east than in western tropical Pacific, the SST response might be stronger in the east than in the west for the same surface heat flux change. Hence, the SST gradient between the eastern tropical and western tropical Pacific is decreased, which leads to a weakened Walker circulation. This agrees with most previous studies on the responses of the Walker circulation to global warming in the CMIP3/5 models [Collins et al., 2010; Kociuba and Power, 2014; Huang and Ying, 2015; Zheng et al., 2016] It should be mentioned that there is decreased downward clear sky LW in Indian subcontinent, which is different from the change in Indo-China Peninsula and South China 
(Figure 9e). This may be because of the warmer surface temperature over Indian subcontinent leading to more upward clear sky LW than those over the other areas (Figure 9d).

Moreover, the mechanism of the Walker circulation response to global warming has been documented by many previous studies [Vecchi et al., 2006; Held and Soden, 2006; He and Soden, 2015]: by constraining the convective mass flux through precipitation and boundary layer moisture $\mathrm{M}=\mathrm{P} / \mathrm{q}$, where $\mathrm{P}, \mathrm{q}$, and $\mathrm{M}$ are precipitation, near-surface specific humidity, and the equivalent convective mass flux, respectively. Since q increases with temperature by following the Clausius-Clapeyron equation while $\mathrm{P}$ increases more slowly, $\mathrm{M}$ must decrease with temperature. Back to the responses to GHG forcing in MetUM-GOML2, the tropical mean Ts increases by $0.61 \mathrm{~K}$. As expected, along with the warming, the tropical mean $\mathrm{q}$ increases at $6.6 \% \mathrm{~K}^{-1}$, while the mean $\mathrm{P}$ increases at $0.8 \% \mathrm{~K}^{-1}$ (not shown). Here we calculate the proportional change in $\mathrm{M}$ as the difference between the proportional changes in P and q: $\frac{\partial M}{M}=\frac{\partial P}{P}-\frac{\partial q}{q}$, following the previous studies [Held and Soden 2006; He and Soden 2015]. The mean $\mathrm{M}$ would decrease at $5.8 \% \mathrm{~K}^{-1}$, with the most pronounced descending air over the maritime continent [Vecchi and Soden, 2006].

\subsection{Changes of atmospheric circulation induced by AA forcing}

There is a belt of high-pressure anomalies from the Northern India to the subtropical Pacific with two anomalous anticyclonic circulation centers, which lead to the suppressed localized convection and the decreased ISR and SEASR (Figure 10a). The center over the Northern India is induced by the cooling related to the local AA emission increases (Figure 
10c, 10e, 11a, and 11b). Moreover, it is exacerbated by the change in local meridional circulation due to the interhemispheric asymmetry in AA forcing, with a sinking anomaly over India and Indo-China peninsula and an ascending anomaly over central Indian Ocean (Figure 10b), corresponding to the change in surface temperatures (Figure 10c).

Tian et al. [2018] has suggested that the anomalous anticyclonic circulation center over the western subtropical Pacific primarily results from AA induced SST changes via performing a set of AGCM simulations. However, the physical process of the SST anomalies in response to AA forcing is not investigated. Because winds from continent to sea prevail in pre-summer season in East Asia and South Asia, AA emissions over Asia can be transported to the western subtropical Pacific and Indian Ocean, and then affect SSTs there. The SST anomalies induced by AA changes in pre-summer season can persist into summer due to large ocean memory. Thus, we look at the spatial patterns of responses in Ts (here use Ts to reflect SST) and aerosol optical depth (AOD) in pre-summer season. With increased AA emissions over Asia from EP to PD, there are cold anomalies with approximately -0.2 - $0.4 \mathrm{~K}$ over the western subtropical Pacific, Arabian Sea and Bay of Bengal in spring (Figure 10d). AOD increases over these regions in pre-summer season, especially in spring with the largest value of 0.21 . Similar changes can also be seen in winter, but with changes being less than in spring (not shown). Hence, the following analysis focuses on spring.

Some key variables for explaining the surface temperature responses in both spring and summer to AA forcing change are illustrated in Figure 12. Increased Asian AA emissions lead 
to large decreases in clear sky shortwave radiation (SW) over large areas in both South Asia and Southeast Asia in both spring and summer (Figure 11b and 11d). Meanwhile, there are also weak but significant decreases in surface clear sky SW radiation over the western subtropical Pacific and Indian Ocean (Figure 11b and 11d). These changes in clear sky SW reflect the role of aerosol-radiation interaction by scattering and absorbing solar radiation [e.g., Boucher et al., 2013]. Large decreases in surface net SW than clear sky SW are partly due to the aerosol-cloud interaction and partly related to cloud changes induced by aerosol induced circulation change (Figure 11a-d). The aerosol-cloud interaction is reflected by a decrease of cloud droplet effective radius and an increase of cloud droplet number concentration over the western subtropical Pacific and Indian Ocean (Figure 11e-f), which increases cloud albedo and cloud lifetime known as "lifetime effect" [Albrecht, 1989; Boucher et al., 2013]. Through both aerosol-radiation interaction and aerosol-cloud interaction, increased AA emissions from EP to PD lead to cooling over the Indian Ocean and the western subtropical Pacific in spring (Figure 10d) while the cooling effect become weaker in summer (Figure 10c) since negative feedbacks related to anomalous local anticyclonic circulations (Figure 10a) that are associated with reduced convection and cloud cover in summer (not shown). Consequently, the increased AA forcing gives rise to the per-summer cooling anomalies over the western subtropical Pacific, and the enhancement of WNPSH [e.g., Lu and Dong, 2001; Tian et al., 2018].

\section{Conclusions and Discussion}

In this study, we have investigated the decadal change of the South Asian summer 
monsoon across the mid-1990s. Firstly, there is significant decreased rainfall over central-northern India and northern Indo-China Peninsula across the mid-1990s in observations. Then we have utilized the coupled atmosphere-ocean-mixed-layer model MetUM-GOML2 to assess the contributions of anthropogenic forcing in shaping the observed changes and to quantify the relative roles of changes in: (1) GHG forcing and (2) AA emissions. Our main findings are as follows.

1. In response to changes in All forcing between the two periods considered (PD and EP), the decreased rainfall can be reproduced over central-northern India and most of SEASM area, with $-0.19 \pm 0.23 \mathrm{~mm} /$ day for the ISR and $-1.26 \pm 0.3 \mathrm{~mm} /$ day for the SEASR. The magnitudes of the changes are comparable to the observed changes. In addition, the changes in lower tropospheric circulation are similar to the observations, with the high-pressure anomalies over central-northern India and the western subtropical Pacific. The results suggest that anthropogenic changes play an important role for the recent observed decadal changes of the ISR and SEASR.

2. Responses to different forcing factors indicate that the changes in GHG forcing plays an important role for the decreased ISR $(-0.29 \pm 0.24 \mathrm{~mm} /$ day $)$ with additional contribution from changes in AA forcing, while the decreased SEASR is mainly contributed by the changes in AA forcing $(-1.0 \pm 0.28 \mathrm{~mm} /$ day $)$. Furthermore, the dynamic processes associated with circulation changes dominate the drought conditions over the Indian subcontinent and Indo-China Peninsula. 
3. The response to increase in GHG forcing is mainly related to the weakened convective mass flux and the warming contrast between the eastern tropical Pacific and the western tropical Pacific, which are associated with the weakened Walker circulation, and these in turn lead to the less rainfall (Figure 12a). Additionally, the change in local Hadley circulation also contributes to the decreased rainfall.

4. The response to AA changes is mainly associated with the anomalous anticyclonic circulations over northern India and the western subtropical Pacific, which is induced by the surface cooling resulted from decreased net downward shortwave radiation (SW). Increased Asian AA emissions decrease downward clear sky SW over South Asia and Southeast Asia through aerosol-radiation interaction. During pre-summer season, AA emissions are transported by mean flow from emission regions to Indian Ocean and the western subtropical Pacific, which induces cooling over there by both aerosol-radiation and aerosol-cloud interactions. The major processes are illustrated in Figure 12b.

Here we showed that the dynamic effect of anthropogenic forcing might have played a dominant role in the recent observed decadal changes of SASM and associated precipitation decrease over South and Southeast Asia. Noted that the thermodynamic process should not be ignored. For example, with continuous increase of GHG concentrations in future, the thermodynamic effect increases gradually. Many studies have shown that the SASM would be faced with increased rainfall but a weakened monsoon circulation under different scenarios [Ueda et al., 2006; Sabade et al., 2011; Turner and Annamalai, 2012; Chen and 
Zhou, 2015]. This is the result of mutual effects between the thermodynamic and dynamic processes.

In this study, the dynamic effect due to the GHG forcing plays a more important role in the decreased rainfall over central-northern India than the AA forcing, which is contrary to what previous studies suggest [e.g., Bollasina et al., 2011; Guo et al., 2015; Li et al., 2015; Zhang and Li, 2016]. This contradiction may be due to differences in models and experiments. First, the previous studies are based on fully coupled models. However, these coupled models exhibit significant biases in model simulated climatological SSTs [Wang et al., 2014] which might have impact on response to external forcing [Ashfaq et al., 2010; He and Soden, 2016].

The model used in this study is a mixed-layer model where the ocean dynamic processes are not included, but has a smaller bias in simulated SSTs (Figure 4a). Secondly, the previous studies are based on the transient experiments in which the external forcing varies with time, because they focus on the drying trend of the ISM since 1950s. Our results are based on the time-slice experiments forced by early period (1964-1981) and present day (1994-2011) anthropogenic forcing, because our concern is the decadal change across the mid-1990s. Consequently, the mechanism about the change in rainfall over central-northern India should be model-dependent and sensitive to the experiment design.

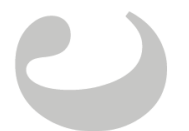

\section{Acknowledgements}

Model simulations are funded by the Met Office Climate Science for Service Partnership Brazil (CSSP Brazil) and by University of Edinburgh. FT is supported by UK-China Research 
\& Innovation Partnership Fund through the Met Office Climate Science for Service Partnership (CSSP) China as part of the Newton Fund. BD is supported by the U.K. National Centre for Atmospheric Science-Climate (NCAS-Climate) at the University of Reading. Data of the model experiments reported in this paper (Table 1) are available without restriction on request from Buwen Dong (b.dong@ reading.ac.uk) at the University of Reading. The CRU data is available to any registered CEDA user. The UDEL and PREC/L data sets are obtained from http://www.esrl.noaa.gov/psd/. The horizontal wind components from the NCEP/NCAR reanalysis version 1.0 are also downloaded from http://www.esrl.noaa.gov/psd/. The HadSLP2 $r$ and HadISST are provided by the UK Met Office Hadley Centre and can be downloaded from at http://www.metoffice.gov.uk/hadobs/hadslp2/ and https://www.metoffice.gov.uk/hadobs/hadisst/. We also thank the three anonymous reviewers for their valuable comments and suggestions that help to greatly improve the manuscript.

\section{References}

Albrecht, B. (1989), Aerosols, cloud microphysics, and fractional cloudiness, Science, 245, 1227-1230, doi:10.1126/science.245.4923.1227.

Allan, R., and T. Ansell (2006), A new globally-complete monthly historical gridded mean sea level pressure dataset (HadSLP2): 1850-2004, J. Clim., 19(22), 5816-5842, doi:10.1175/JCLI3937.1.

Ashfaq, M., C. Skinner, and N. Diffenbaugh (2010), Influence of SST biases on future climate change projections. Clim. Dyn., 36, 1303-1319.

Bellouin, N., G. Mann, M. Woodhouse, C. Johnson, K. Carslaw, and M. Dalvi (2013), Impact of the model aerosol scheme GLOMAP-mode on aerosol forcing in the Hadley Centre Global Environmental Model. Atmos. Chem. Phys., 13, 3027-3044.

Bollasina, M. A., Y. Ming, and V. Ramaswamy (2011), Anthropogenic aerosols and the weakening of the South Asian summer monsoon, Science, 334(6055), 502-505, doi: 10.1126/science. 1204994 .

Boucher, O., D. Randall, P. Artaxo, C. Bretherton, G. Feingold, P. Forster, et. al. (2013), Clouds and aerosols. In T. Stocker, et al. (Eds.), Climate change 2013: The physical science basis. Contribution of Working Group I to the Fifth Assessment Report of the 
Intergovernmental Panel on Climate Change (pp. 571-657). Cambridge, United Kingdom and New York: Cambridge University Press.

Chen, M., P. Xie, J. Janowiak, and P. Arkin (2002), Global Land Precipitation: A 50-yr Monthly Analysis Based on Gauge Observations, J. of Hydrometeorology, 3, 249-266.

Chen, X., and T. Zhou (2015), Distinct effects of global mean warming and regional sea surface warming pattern on projected uncertainty in the South Asian summer monsoon, Geophys. Res. Lett., 42, 9433-9439, doi:10.1002/2015GL066384.

Choi, J. W., Y. Cha, and R. Lu (2017), Interdecadal variation of summer monsoon over the southern part of South Asia in mid-1990s, Int. J. Climatel., 37, 1138-1146, doi: 10.1002/joc.5071.

Chou, C., J. D. Neelin, C. A. Chen, and J. Y. Tu (2009), Evaluating the "rich-getricher" mechanism in tropical precipitation change under global warming, J. Clim., 22(8), $1982-20$.

Chung, C. E., and V. Ramanathan (2006) Weakening of North Indian SST gradients and the monsoon rainfall in India and the Sahel, J. Clim., 19, 2036-2045.

Collins, M., S. An, W. Cai, A. Ganachaud et al (2010) The impact of global warming on the tropical Pacific Ocean and El Niño, Nat. Geosci., 3, 391-397.

Cui, X., Y. Gao, J. Sun, D. Guo, S. Li, O. Johannessen (2014), Role of natural external forcing factors in modulating the Indian summer monsoon rainfall, the winter North Atlantic Oscillation and their relationship on inter-decadal timescale, Clim. Dyn., 43, 2283-2295, doi: 10.1007/s00382-014-2053-4.

Dai, A., J. Fyfe, P. Xie, X. Xin (2015), Decadal modulation of global surface temperature by internal climate variability, Nat. Clim. Change, 5, 555-559.

Ding, Y. (2007), The variability of the asian summer monsoon, J. Meteor. Soc., 85, 21-54, doi: $10.2151 /$ jmsj.85B.21.

Ding, Y., Y. Sun, Z. Wang, Y. Zhu, and Y. Song (2009), Inter- decadal variation of the summer precipitation in China and its association with decreasing Asian summer 
monsoon Part II: Possible causes, Int. J. Climatel., 29, 1926-1944, doi: 10.1002/joc. 1759 .

Dong, B., R. Sutton, W. Chen, X. Liu, R. Lu, and Y. Sun (2016), Abrupt Summer Warming and Changes in Temperature Extremes over Northeast Asia since the mid-1990s: Drivers and Physical Processes, Adv. Atmos. Sci., 33, 1005-1023.

Dong, B., R. T. Sutton, L. Shaffrey (2017a), Understanding the rapid summer warming amd changes in temperature extremes since the mid-1990s over Western Europe, Clim. Dyn., 48, 1537-1554, doi: 10.1007/s00382-016-3158-8.

Dong, B., R. T. Sutton, L. Shaffrey, and N. P. Klingaman (2017b), Attribution of forced decadal climate change in coupled and uncoupled ocean-atmosphere model experiments, J. Clim., 30(16), 6203-6223.

Dong, L., T. Zhou, and X. Chen (2014), Changes of Pacific Decadal Variability in the Twentieth Century Driven by Internal Variability, Greenhouse Gases and Aerosols, Geophys. Res. Lett., 41, 8570-8577.

Edwards, J., and A. Slingo (1996), Studies with a flexible new radiation code. I: Choosing a configuration for a large-scale model. Quart, J. Roy. Meteor. Soc., 122, 689-719

Feichter, J., E. Roeckner, U. Lohmann, and B. Liepert (2004), Nonlinear aspects of the climate response to greenhouse gas and aerosol forcing, J. Clim., 17, 2384-2398.

Ganguly, D., P. Rasch, H. Wang, and J. Yoon (2012), Fast and slow responses of the South Asian monsoon system to anthropogenic aerosols, Geophys. Res. Lett., 39, L18804, doi:10.1029/2012GL053043.

Goswami, B., V. Krishnamurthy, H. Annmalai (1999), A broad-scale circulation index for the interannual variability of the Indian summer monsoon, Q. J. R. Meteorol. Soc., 125, 611-633, doi: 10.1002/qj.49712555412.

Goswami, B., M. Madhusoodanan, C. Neema, and D. Sengupta (2006), A physical mechanism for North Atlantic SST influence on the Indian summer monsoon, Geophys. Res. Lett., 33, L02706, doi: 10.1029/2005GL024803. 
Guo, L., A. Turner, E. Highwood (2015), Impacts of 20th century aerosol emissions on the South Asian monsoon in the CMIP5 models, Atmos. Chem. Phys., 15 (11), 6367-6378, doi: $10.5194 /$ acp-15-6367-2015.

He, J., and B. Soden (2015), Anthropogenic Weakening of the Tropical Circulation: The Relative Roles of Direct CO2 Forcing and Sea Surface Temperature Change, J. Clim., 28, 8728-8742, doi: 10.1175/JCLI-D-15-0205.1.

He, J., and B. Soden (2016), The impact of SST biases on projections of anthropogenic climate change: A greadter role for atmosphere-only models? Geophys. Res. Lett., 43, 7745-7750.Held, M., and B. Soden (2006), Robust responses of the hydrological cycle to global warming, J. Clim., 19, 5686-5699, doi:10.1175/JCLI3990.1.

Hirons, L. C., N. P. Klingaman, S. J. Woolnough (2015), MetUM-GOML: a near-globally coupled atmosphere-ocean-mixed-layer model, Geosci. Model. Dev., 8, 363-379.

Hong, X., R. Lu, and S. Li (2017), Amplified summer warming in Europe-West Asia and Northeast Asia after the mid-1990s, Env. Res. Lett., 12, 094007.

Huang, P., and J. Ying (2015), A multimodel ensemble pattern regression method to correct the tropical Pacific SST change patterns under global warming, J. Clim., 28, 4706-4723.

Jones, C., J. Hughes, N. Bellouin, S. Hardiman, G. Jones, et al (2011), The HadGEM2-ES implementation of CMIP5 centennial simulations, Geosci. Model. Dev., 4, 543-570.

Kalnay, E., M. Kanamitsu, R. Kistler, W. Collins, et al. (1996), The NCEP/NCAR 40-year reanalysis project, Bull. Amer. Meteor. Soc., 77, 437-470, doi: 10.1175/1520-0477(1996)077<0437:TNYRP>2.0.CO;2.

Klingaman, N. P., S. J. Woolnough, H. Weller, J. M. Slingo (2011), The impact of finer-resolution air-sea coupling on the intraseasonal oscillationof the Indian monsoon, J. Clim., 24(10), 2451-2468.

Kociuba, G., and S. Power (2014), Inability of CMIP5 Models to Simulate Recent Strengthening of the Walker Circulation: Implications for Projections, J. Clim., 28, 20-35. 
Kosaka, Y., and S. P. Xie (2013), Recent global-warming hiatus tied to equatorial Pacific surface cooling, Nature, 501, 403-407.

Krishnan, R., T. Sabin, R. Vellore, M. Mujumdar, J. Sanjay, B. Goswami, F. Hour- din, J.-L. Dufresne, and P. Terray (2016), Deciphering the desiccation trend of the South Asian monsoon hydroclimate in a warming world, Clim. Dyn., 47, 1007-1027.

Krishnamurthy, V., and B. Goswami B (2000), Indian Monsoon-ENSO Relationship on Interdecadal Timescale, J. Clim., 13, 579-595, doi: 10.1175/1520-0442(2000)013<0579:IMEROI>2.0. CO;2.

Krishnamurthy, L., and V. Krishnamurthy (2014), Influence of PDO on South Asian summer monsoon and monsoon-ENSO relation, Clim. Dyn., 42(9-10), 2397-2410, doi: 10.1007/s00382-013-1856-z.

Kumar, K., B. Rajagopalan, M. Cane (1999), On the weakening relationship between the Indian monsoon and ENSO, Science, 284, 2156-2159, doi: 10.1126/science.284.5423.2156.

Lamarque, J. F., T. C. Bond, V. Eyring, C. Granier, A. Heil, Z. Klimont, et. al. (2010), Historical (1850-2000) gridded anthropogenic and biomass burning emissions of reactive gases and aerosols: methodology and application, Atmos. Chem. Phys., 10(15), $7017-7039$.

Lamarque, J.F., G. P. Kyle, M. Meinshausen, K. Riahi, S. J. Smith, D. P. van Vuuren et. al. (2011), Global and regional evolution of short-lived radiatively-active gases and aerosols in the representative concentration pathways, Clim. Change., 109(1-2), 191.

Large, W. G., J. C. McWilliams, S. C. Doney (1994), Oceanic vertical mixing: A review and a model with a nonlocal boundary layer parameterization, Rev. Geophys., 32(4), 363403.

Lau, K. M., M. K. Kim, and K. M. Kim (2006), Asian summer monsoon anomalies induced by aerosol direct forcing: the role of the Tibetan Plateau, Clim. Dyn., 26, 855-864, doi:10.1007/s00382-006-0114-z, 2006. 
Lau, W., and K. Kim (2017), Competing Influences of Greenhouse Warming and Aerosols on Asian Summer Monsoon Circulation and Rainfall, Asia-Pac. J. Atmos. Sci., 53(2), 181-194, doi: 10.1007/s13143-017-0033-4.

Lau, W., K. Kim, and L. Leung (2017), Changing circulation structure and precipitation characteristics in Asian monsoon regions: greenhouse warming vs. aerosol effects, Geosci. Lett., 4, 28, doi: 10.1186/s40562-017-0094-3.

Li, J., and Q. Zeng (2002), A unified monsoon index, Geophys. Res. Lett., 29(8), 1274, doi:10.1029/2001GL013874, 2002.

Li, S., and R. Mahmood (2017), Projecting South Asian summer precipitation in CMIP3 models: a comparison in simulations with black carbon and those without black carbon, J. Meteor. Soc., 31(1), 196-203, doi: 10.1007/s13351-017-6101-y.

Li, S., J. Perlwitz, X. Quan, and M. Hoerling (2008), Modelling the influence of North Atlantic multidecadal warmth on the Indian summer rainfall, Geophys. Res. Lett., 35, L05804, doi: 10.1029/2007GL032901.

Li, X., M. Ting, C. Li, and N. Henderson (2015), Mechanisms of Asian summer monsoon changes in response to anthropogenic forcing in CMIP5 models, J. Clim., 28(10), 41074125.

Li, X., and M. Ting (2017), Understanding the Asian summer monsoon response to greenhouse warming: the relative roles of direct radiative forcing and sea surface temperature change, Clim. Dyn., 49(7-8), 2863-2880.

Li, Z., K. M. Lau, V. Ramanathan, et. al. (2016), Aerosol and monsoon climate interactions over Asia, Rev. Geophys., 54, 866-929.

Li, Z., J. Guo, A. Ding, H. Liao, J. Liu, et. al. (2017), Aerosol and boundary-layer interactions and impact on air quality, National Science Review, 4, 810-833.

Lu, R.Y., and B. W. Dong (2001), Westward extension of North Pacific subtropical high in summer, J. Meteor. Soc. Japan., 79, 1229-1241. 
Luo, F., S. Li, and T. Furevik (2017), Weaker connection between the Atlantic multidecadal oscillation and Indian summer rainfall since the mid-1990s, Atmos. Oceanic. Sci. Lett., doi: $10.1080 / 16742834.2018 .1394779$.

Mahmood, R., and S. Li (2014), Remote Influence of South Asian Black Carbon Aerosol on East Asian Summer Monsoon, Int. J. Climatel., 34(1), 36-48, doi: 10.1002/joc.3664.

Ming, Y., and V. Ramaswamy (2009), Nonlinear climate and hydrological responses to aerosol effects, J. Clim., 22, 1329-1339.

Ming, Y., and V. Ramaswamy (2011), A model investigation of aerosolinduced changes in tropical circulation, J. Clim., 24(19), 5125-5133, doi: 10.1175/2011JCLI4108.1.

Misra, V., and S. DiNapoli (2014), The variability of the Southeast Asian summer monsoon, Int. J. Climatel., 34, 893-901.

Mitchell, T., and P. Jones (2005), An improved method of constructing a database of monthly climate observations and associated high resolution grid, Int. J. Climatel., 25, 693-712, doi:10. 1002/joc.1181.

Ramesh, K., and P. Goswami (2007), Reduction in temporal and spatial extent of the Indian summer monsoon, Geophys. Res. Lett., 34, L23704, doi: 10.1029/2007GL031613.

Rayner, N., D. Parker, E. Horton, C. Folland, L. Alexander, D. Rowell, E. Kent, A. Kaplan (2003), Global analyses of sea surface temperature, sea ice, and night marine air temperature since the late nineteenth century, J. Geophys. Res., 108(D14), 4407, doi:10.1029/2002JD002670.

Rotstayn, L. D., and U. Lohmann (2002), Tropical rainfall trends and the indirect aerosol effect, $\quad J . \quad$ Clim., $\quad 15(15), \quad 2103-2116, \quad$ doi: 10.1175/1520-0442(2002)015<2103:TRTATI>2.0.CO;2.

Roy, I., R. Tedeschi, and M. Collins (2017), ENSO teleconnections to the Indian summer monsoon in observations and models, Int. J. Climatel., 37, 1794-1813.

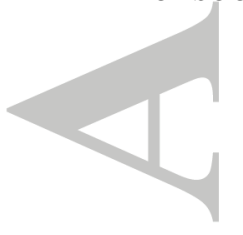


Sabade, S., A. Kulkarni, and R. Kripalani (2011), Projected changes in South Asian summer monsoon by multi-model global warming experiments, Theor. Appl. Climatol., 103, 543-565.

Samset, B., G. Myhre, M. Forster, et al (2016), Fast and slow precipitation responses to individual climate forcers: A PDRMIP multimodel study, Geophys. Res. Lett., 43, $2782-2791$.

Sankar, S., L. Svendsen, B. Gokulapalan, P. Joseph, and O. Johannessen (2016), The relationship between Indian summer monsoon rainfall and Atlantic multidecadal variability over the last 500 years, Tellus A, 68, 1-14.

Shi, F., J. Li, and R. Wilson (2014), A tree-ring reconstruction of the South Asian summer monsoon index over the past millennium, Scientific Reports, 4, 6739.

Shiogama, H., D. A. Stone, T. Nagashima, T. Nozawa, and S. Emori (2012), On the linear additivity of climate forcing-response relationships at global and continental scales, Int. J. Climatel., 33, 2542-2550.

Song, F., and T. Zhou (2014a), The climatology and interannual variability of East Asian summer monsoon in CMIP5 coupled models: Does air-sea coupling improve the simulations? J. Clim., 27, 8761-8777

Song, F., and T. Zhou (2014b), Interannual Variability of East Asian Summer Monsoon Simulated by CMIP3 and CMIP5 AGCMs: Skill Dependence on Indian Ocean-Western Pacific Anticyclone Teleconnection, J. Clim., 27, 1679-1697.

Steinman, B. A., M. E. Mann, and S. K. Miller (2015), Atlantic and Pacific multidecadal oscillations and Northern Hemisphere temperatures, Science, 347, 988-991.

Sun, Y., and Y. Ding (2011), Responses of South and East Asian summer monsoons to different land-sea temperature increases under a warming scenario, Chinese. Sci. Bull., 56, 2718-2726, doi: 10.1007/s11434-011-4602-0. 
Tian, F., B. Dong, J. Robson, and R. Sutton (2018), Forced decadal changes in the East Asian summer monsoon: the roles of greenhouse gases and anthropogenic aerosols, Clim. Dyn., doi: $10.1007 / \mathrm{s} 00382-018-4105-7$.

Trenberth, K. E., and C. J. Guillemot (1995), Evaluation of the global atmospheric moisture budget as seen from analyses, J. Clim., 8(9), 2255-2272.

Tsai, C., S. Behera, and T. Waseda (2015), Indo-China Monsoon Indices, Scientific Reports, $5,8107$.

Turner, A., P. Inness, J. Slingo (2005), The role of the basic state in the ENSO-monsoon relationship and implications for predictability, Q. J. R. Meteorol. Soc., 131, 781-804.

Turner, A., and H. Annamalai (2012), Climate change and the South Asian summer monsoon, Nature Climate Change, 2, 587-595, doi: 10.1038/nclimate1495.

Ueda, H., A. Iwai, K. Kuwako, and M. Hori (2006), Impact of anthropogenic forcing on the Asian summer monsoon as simulated by eight GCMs, Geophys. Res. Lett., 33, L06703, doi:10.1029/2005GL025336.

Valcke, S., A. Caubel, D. Declat, and L. Terray (2003), OASIS3 ocean atmosphere sea ice soil user's guide, Prisim project report, 2.

Vannière, B., E. Guilyardi, G. Madec, F. J. Doblas-Reyes, and S. Woolnough (2013), Using seasonal hindcasts to understand the origin of the equatorial cold tongue bias in CGCMs and its impact on ENSO, Clim. Dyn., 40(3-4), 963-981.

Vecchi, G. A., and B. J. Soden (2006), Global warming and the weakening of the tropical circulation, J. Clim., 20(17), 4316-4340, doi: 10.1175/JCLI4258.1.

Waliser, D. E., R. Murtugudde, and L. E. Lucas (2004), Indo-Pacific ocean response to atmospheric intraseasonal variability: 2. Boreal summer and the Intraseasonal Oscillation, J. Geophys. Res. Oceans, 109(C3), 1-26.

Walters, D. N., M. J. Best, A. C. Bushell, D. Copsey, J. M. Edwards, P. D. Falloon, and M. J. Roberts (2011), The met office unified model global atmosphere 3.0/3.1 and JULES global land 3.0/3.1 configurations, Geosci. Model. Dev., 4(4), 919. 
Walter, D., M. Brooks, I. Boutle, T. Melvin, et. al. (2017), The Met Office Unified Model Global Atmosphere 6.0/6.1 and JULES Global Land 6.0/6.1 configurations, Geoscientific. Model. Dev., 10 (4), 1487-1520, doi: 10.5194/gmd-10-1487-2017.

Wang, B., and Z. Fan (1999), Choice of South Asian Summer Monsoon indices, B, Am. Meteorol. Soc., 80, 629-638.

Wang, C., L. Zhang, S. Lee, L. Wu, and C. R. Mechoso (2014), A global perspective on CMIP5 climate model biases, Nature Climate Change, 4, 201-205, doi: 10.1038/nclimate2118.

Wang, D., B. Zhu, Z. Jiang, X. Yang, and T. Zhu (2016), The impact of the direct effects of sulfate and black carbon aerosols on the sub- seasonal march of the East Asian subtropical summer monsoon, J. Geophys. Res. Oceans, 121, 2610-2625.

Wang, Z., L. Lei, M. Yang, Y. Xu, and J. Li (2017), Disentangling fast and slow responses of the East Asian summer monsoon to reflecting and absorbing aerosol forcings, Atmos. Chem. Phys., 17, 11075-11088.

Wang, T., H. J. Wang, O. H. Ottert, Y. Q. Gao, L. L. Suo, T. Furevik, and L. Yu (2013), Anthropogenic agent implicated as a prime driver of shift in precipitation in eastern China in the late 1970s, Atmos. Chem. Phys., 13(24), 12433.

Webster, P. J., and S. Yang (1992), Monsoon and ENSO: selectively interactive systems, Q. J. R. Meteorol. Soc., 118, 877-926.

Webster, P., V. Magana, T. N. Palmer, J. Shukla, R. A. Tomas, M. Yanai, and T. Yasunari (1998), Monsoons: Processes, predictability, and the prospects for prediction, $J$. Geophys. Res., 103, 451-510, doi: 10.1029/97JC02719.

Willmott, C. J., and K. Matsuura (2001), Terrestrial Air Temperature and Precipitation: Monthly and Annual Time Series (1950-1999), http://climate.geog.udel.edu/ climate/html_pages/README.ghcn_ts2.html.

$\mathrm{Xu}, \mathrm{Y}$., and S. P. Xie (2015), Ocean mediation of tropospheric response to reflecting and absorbing aerosols, Atmos. Chem. Phys., 15, 5827-5833. 
Zhang, L., H. Liao, and J. Li (2010), Impact of the Southeast Asian summer monsoon strength on the outflow of aerosols from South Asia, Ann. Geophys., 28, 277-287.

Zhang, L., and T. Li (2016), Relative roles of anthropogenic aerosols and greenhouse gases in land and oceanic monsoon changes during past 156 years in CMIP5 models, Geophys. Res. Lett., 43, 5295-5301, doi:10.1002/2016GL069282.

Zhang, R., and T. L. Delworth (2005), Impact of Atlantic multidecadal oscillations on India/Sahel rainfall and Atlantic hurricanes, Geophys. Res. Lett., 33, L17712, doi:10.1029/2006GL026267.

Zheng, T., S. Xie, L. Lv, and Z. Zhou (2016), Inter-model uncertainty in ENSO amplitude change tied to Pacific Ocean warming pattern, J. Clim., 29, 7265-7279.

Zhou, X. M., S. Li, F. Luo, Y. Gao, and T. Furevik (2015), Air-Sea Coupling Enhances East Asian Winter Climate Response to the Atlantic Multidecadal Oscillation (AMO), $A d v$. Atmos. Sci., 32, 1647-1659, doi: 10.1007/s00376-015-5030-x.

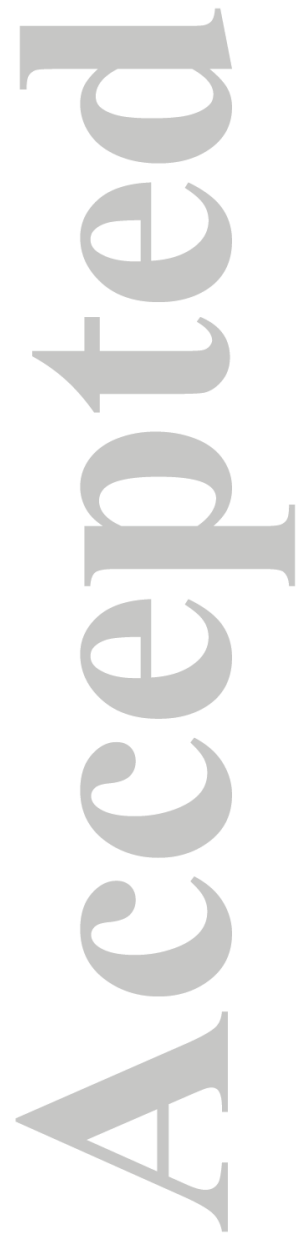




\section{Figure captions}

Table 1. Summary of numerical experiments

Figure 1. Time series of (a-c) the ISR and (d-f) the SEASR anomalies relative to climatology of 1964-2011 for the three observational datasets. The solid orange lines indicate the time mean rainfall anomalies during the early period (EP, 1964-1981) and present day (PD, 1994-2011), and the mean values are given in the upper left corners (units: mm/day). P values based on the two-tailed student's t test are given in the upper right corners.

Figure 2. Spatial patterns of differences in $(\mathrm{a}-\mathrm{c})$ rainfall for the three observational datasets (units: $\mathrm{mm} /$ day) and (d) SLP (units: $\mathrm{hPa}$ ) and wind at $850 \mathrm{hPa}$ (units: $\mathrm{m} / \mathrm{s}$ ) in summer between PD and EP periods. Boxes indicate selected regions of the ISR and SEASR. Vertical lines indicate statistical significance at the $10 \%$ level using a two-tailed Student t-test.

Figure 3. Summer climate state of rainfall in (a-c) the three observational datasets and (d) MetUM-GOML2 for PD period (units: mm/day). Summer climate state of SLP (units: hPa) and $850 \mathrm{hPa}$ horizontal wind (units: $\mathrm{m} / \mathrm{s}$ ) in (e) observations and (f) MetUM-GOML2 for PD period. Boxes indicate selected regions of the ISR and SEASR.

Figure 4. (a) Summer mean SST bias of MetUM-GOML2 simulation relative to HadISST for PD period. Summer mean SST difference between PD and EP in (b) Observations and (c) MetUM-GOML2. (units: ${ }^{\circ} \mathrm{C}$ ) 
Figure 5. Spatial patterns of responses to All forcing. (a) precipitation (units: mm/day) (b) SLP (units: $\mathrm{hPa}$ ) and $850 \mathrm{hPa}$ wind (units: $\mathrm{m} / \mathrm{s}$ ) in summer. Box indicates selected region of the ISR and SEASR. Black dots in (a), black lines and black arrowheads in (b) indicate statistical significance at the $10 \%$ level using a two-tailed Student t-test.

Figure 6. Spatial patterns of responses in summer rainfall to (a) GHG forcing and (b) AA forcing. Black dots indicate statistical significance at the $10 \%$ level using a two-tailed Student t-test. (c) Area averaged rainfall over selected region of the ISR and SEASR. Error bars indicate the standard error of difference of the variables. (units: $\mathrm{mm} /$ day)

Figure 7. (a-c) differences of the vertically integrated moisture transport convergence between PD and EP experiments in summer for All Forcing, GHG forcing and AA forcing respectively. (d-f) same as (a-c) but the differences of dynamical effect. (g-i) same as (a-c) but the differences of thermodynamic effect. (units: $\mathrm{mm} /$ day)

Figure 8. Area averaged precipitation (Pr), vertically integrated moisture transport convergence (MT), dynamic effect (DY) and thermodynamic effect (TH) in (a) over ISR region and (b) over SEASR region in response to All Forcing (gray), GHG forcing (green) and AA forcing (pink). Error bars indicate the standard error of difference of the variables. (units: $\mathrm{mm} /$ day)

Figure 9. Spatial patterns of responses to GHG forcing in summer. (a) SLP (units: hPa) and $850 \mathrm{hPa}$ wind (units: $\mathrm{m} / \mathrm{s}$ ), (b) Zonal mean meridional stream function (units: $\mathrm{kg} / \mathrm{s} \times 10^{10}$ ) and 
wind anomalies (units: $\left.\mathrm{m} / \mathrm{s} \times 10^{-3}\right)$ averaged over sector $\left(60^{\circ} \mathrm{E}-100^{\circ} \mathrm{E}\right),(\mathrm{c})$ Geopotential height (units: $\mathrm{m}$ ) and wind anomalies (units: $\mathrm{m} / \mathrm{s} \times 10^{-3}$ ) averaged meridionally over sector $\left(10^{\circ} \mathrm{S}-10^{\circ} \mathrm{N}\right),(\mathrm{d})$ Surface temperature (Ts) (units: ${ }^{\circ} \mathrm{C}$ ), and (e) net clear sky LW (units: $\mathrm{W} \mathrm{m}^{-2}$, positive values mean download). Green lines, black dots and black arrowheads indicate statistical significance at the $10 \%$ level using a two-tailed Student t-test.

Figure 10. Spatial patterns of responses to AA forcing in summer. (a) SLP (units: hPa) and 850 $\mathrm{hPa}$ wind (units: $\mathrm{m} / \mathrm{s}$ ) and (b) Zonal mean meridional stream function (units: $\mathrm{kg} / \mathrm{s} \times 10^{10}$ ) and wind anomalies (units: $\left.\mathrm{m} / \mathrm{s} \times 10^{-3}\right)$ averaged over sector $\left(60^{\circ} \mathrm{E}-100^{\circ} \mathrm{E}\right)$. Surface temperature $(\mathrm{Ts})$ in (c) summer and (d) spring (units: ${ }^{\circ} \mathrm{C}$ ). (e) all aerosols AOD in summer. (f) all aerosols AOD and climate state of $850 \mathrm{hPa}$ horizontal wind (units: $\mathrm{m} / \mathrm{s}$ ). Black dots, green lines and black thick arrowheads indicate statistical significance at the $10 \%$ level using a two-tailed Student t-test.

Figure 11. Spatial patterns of responses to AA forcing. (a) net surface SW and (b) net clear sky SW in summer (units: $\mathrm{W} \mathrm{m}^{-2}$, positive values mean download). (c-d) same as (a-b) but for spring. (e) cloud droplet effective radius (units: um) and (f) cloud droplet number concentration (units: $10^{10} \mathrm{~m}^{-2}$ ) in spring. Black dots indicate statistical significance at the $10 \%$ level using a two-tailed Student t-test.

Figure 12. Schematic diagram illustrating the major processes of the responses in the ISR and SEASR to (a) GHG forcing and (b) AA forcing. 
Table 1. Summary of numerical experiments

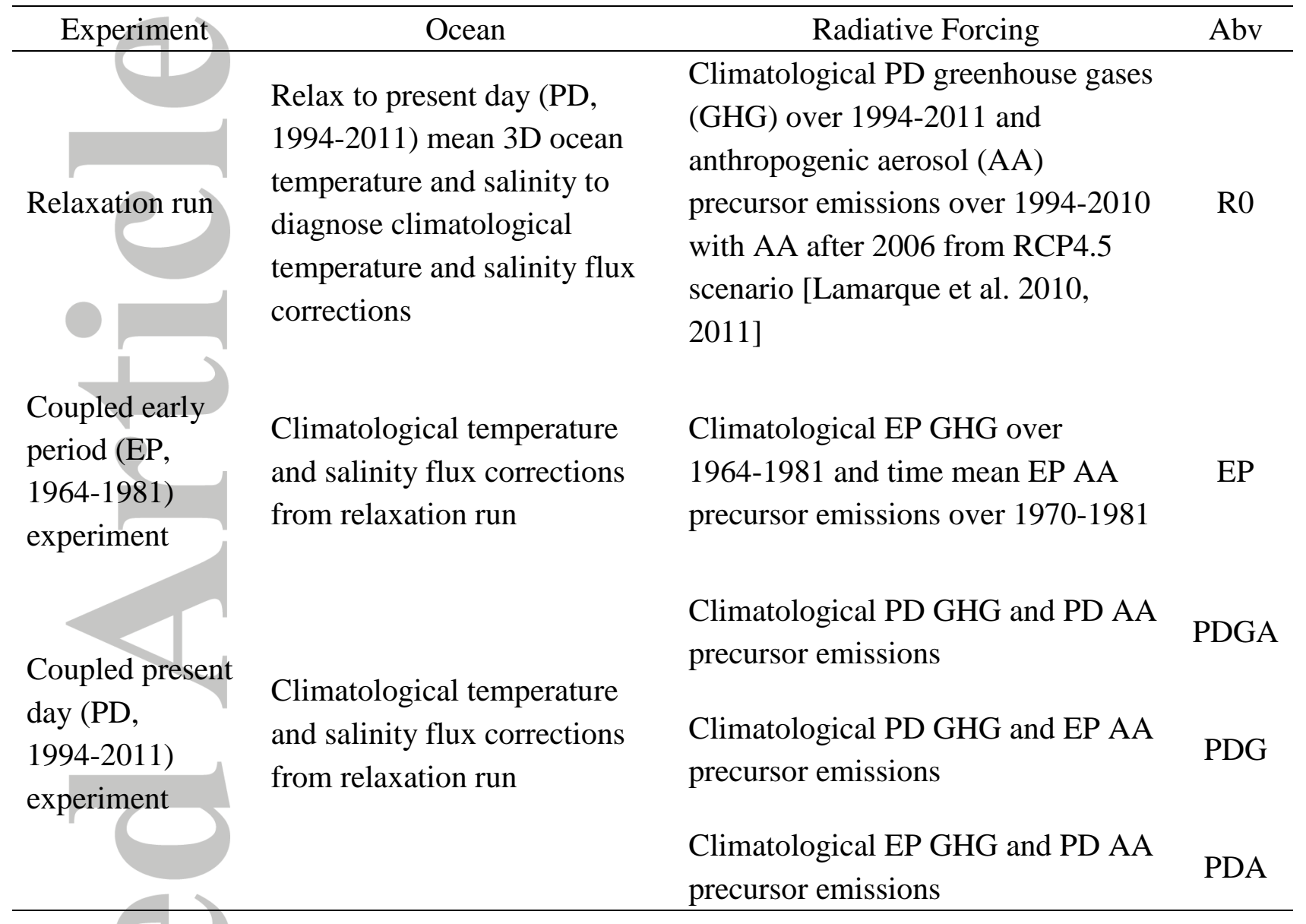


ISR
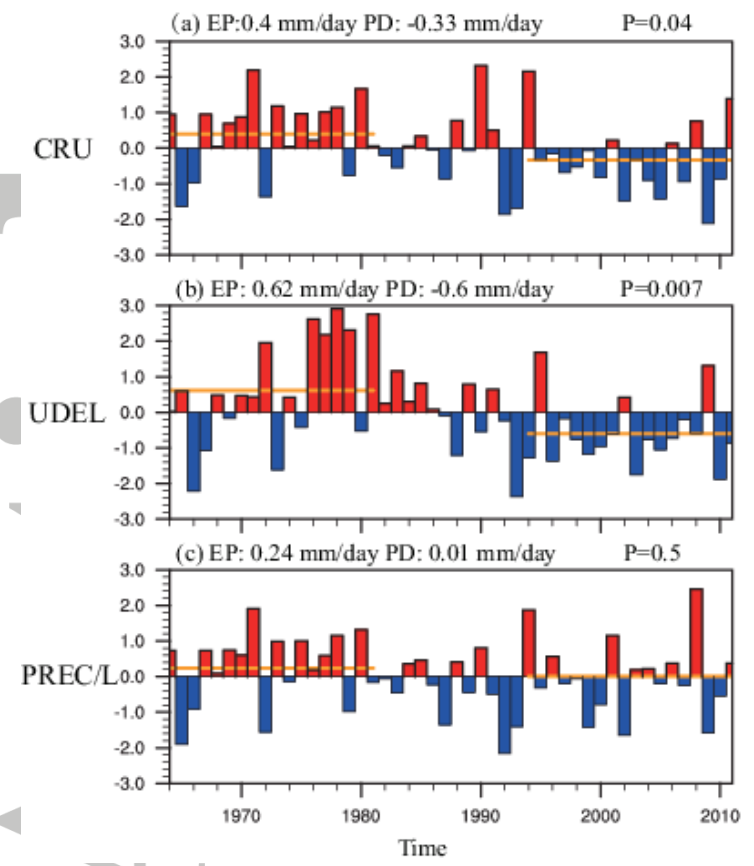

SEASR
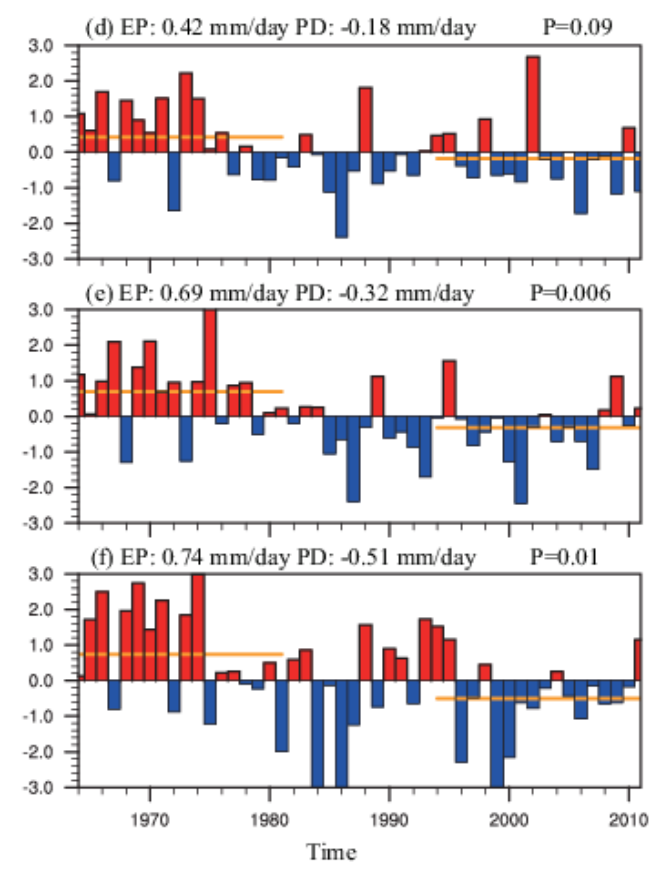

Figure 1. Time series of (a-c) the ISR and (d-f) the SEASR anomalies relative to climatology

of 1964-2011 for the three observational datasets. The solid orange lines indicate the time mean rainfall anomalies during the early period (EP, 1964-1981) and present day (PD, 1994-2011), and the mean values are given in the upper left corners (units: mm/day). P values based on the two-tailed student's t test are given in the upper right corners. 


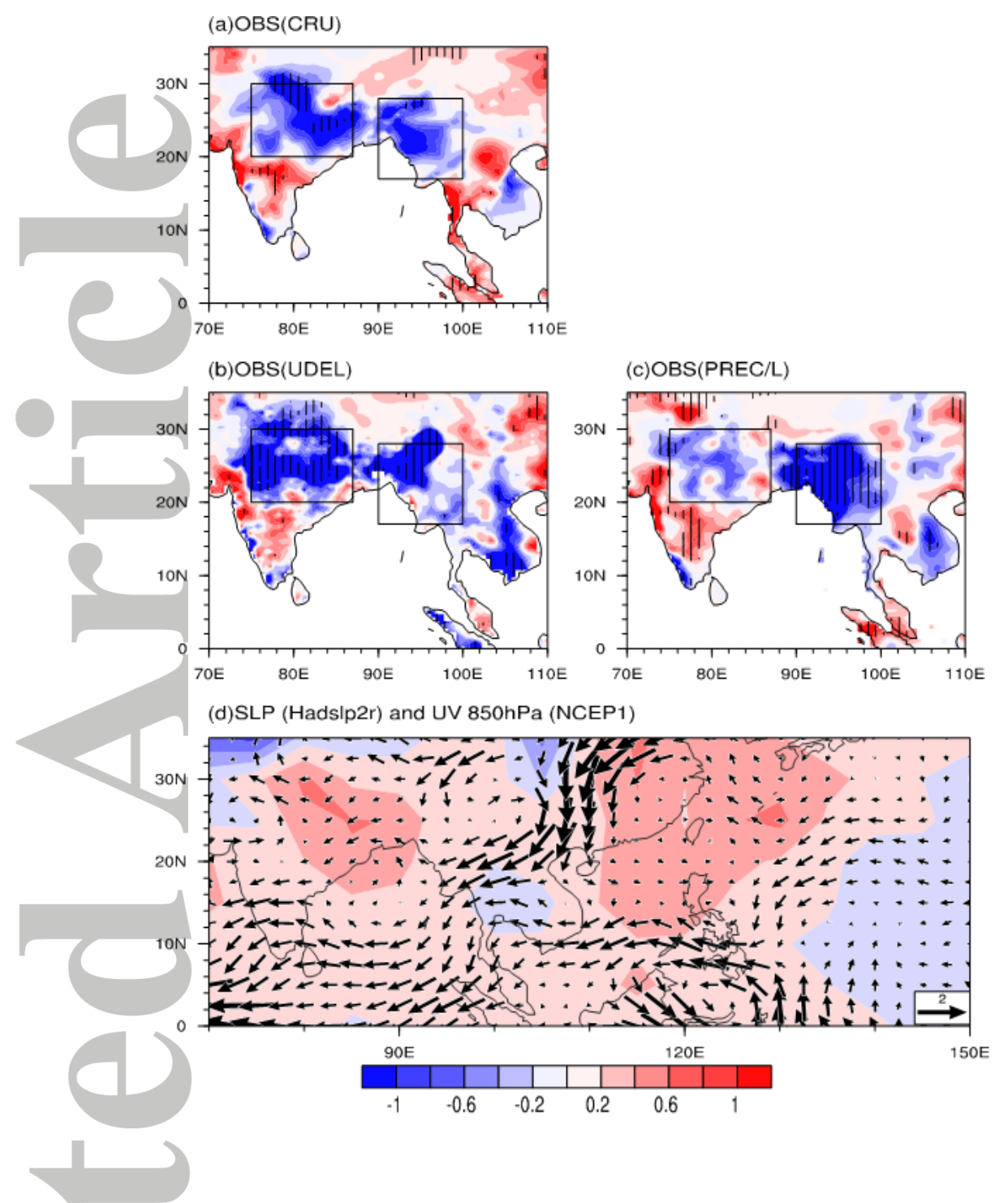

Figure 2. Spatial patterns of differences in $(a-c)$ rainfall for the three observational datasets (units: $\mathrm{mm} /$ day) and (d) SLP (units: $\mathrm{hPa}$ ) and wind at $850 \mathrm{hPa}$ (units: $\mathrm{m} / \mathrm{s}$ ) in summer between PD and EP periods. Boxes indicate selected regions of the ISR and SEASR. Vertical lines indicate statistical significance at the $10 \%$ level using a two-tailed Student t-test. 

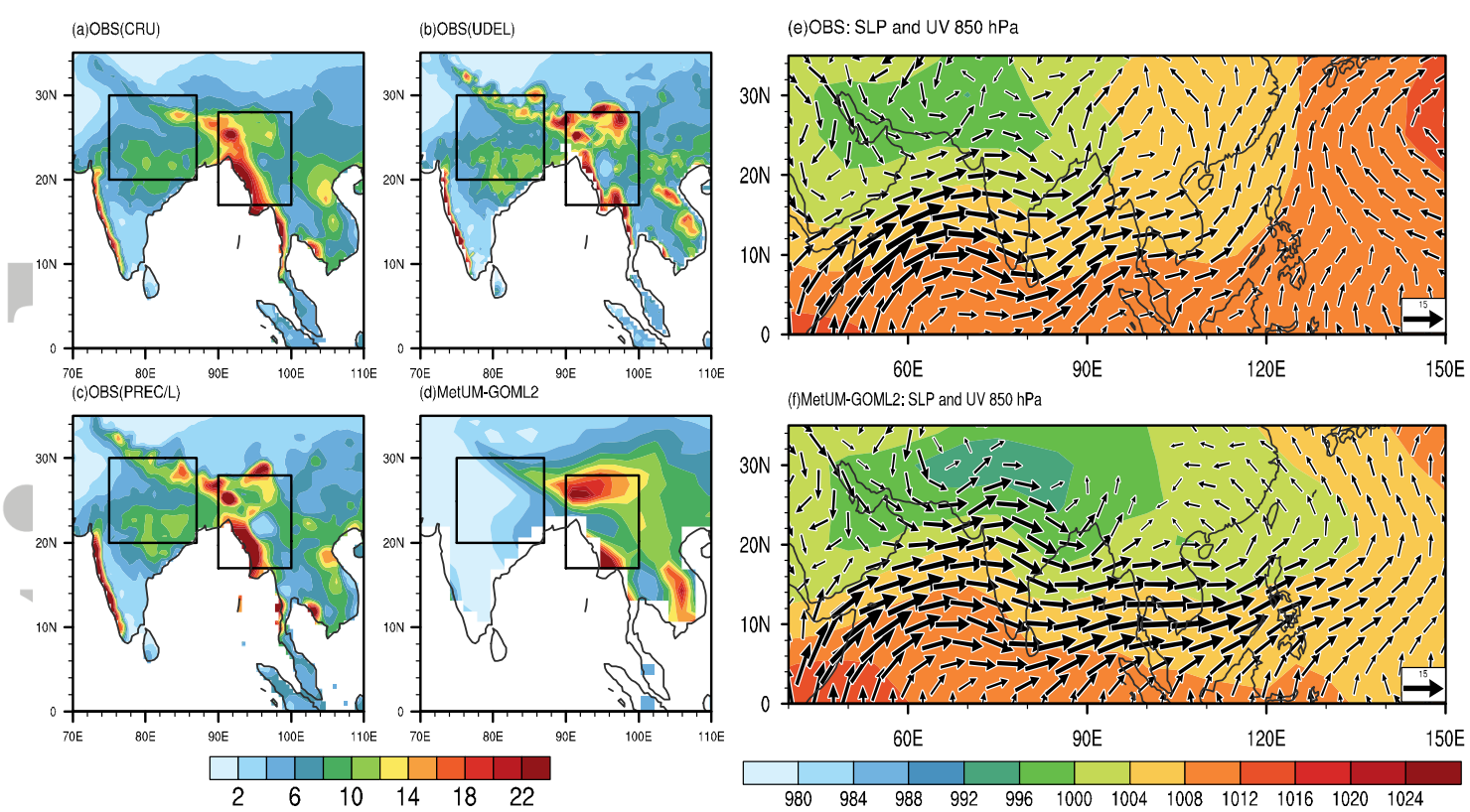

Figure 3. Summer climate state of rainfall in (a-c) the three observational datasets and (d) MetUM-GOML2 for PD period (units: mm/day). Summer climate state of SLP (units: hPa) and $850 \mathrm{hPa}$ horizontal wind (units: $\mathrm{m} / \mathrm{s}$ ) in (e) observations and (f) MetUM-GOML2 for PD period. Boxes indicate selected regions of the ISR and SEASR. 
(a)summer mean SST bias for 1994-2011

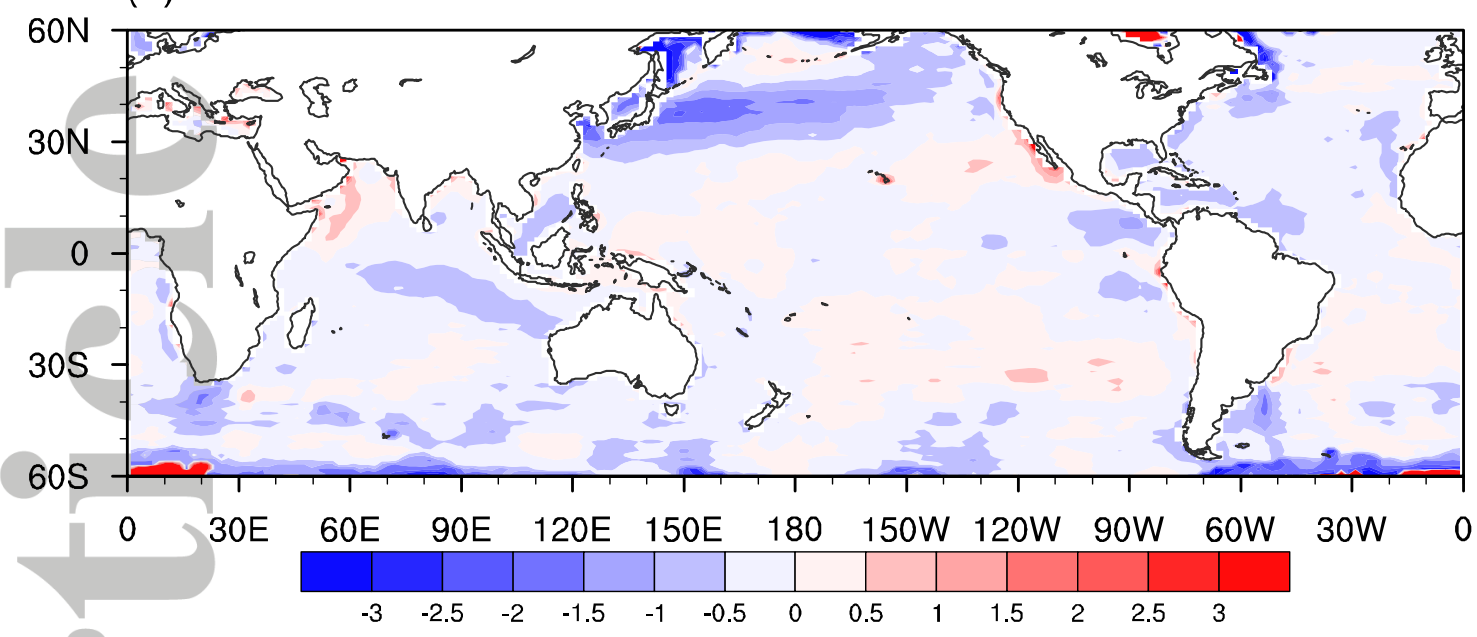

(b)OBS:summer SST change between PD and EP

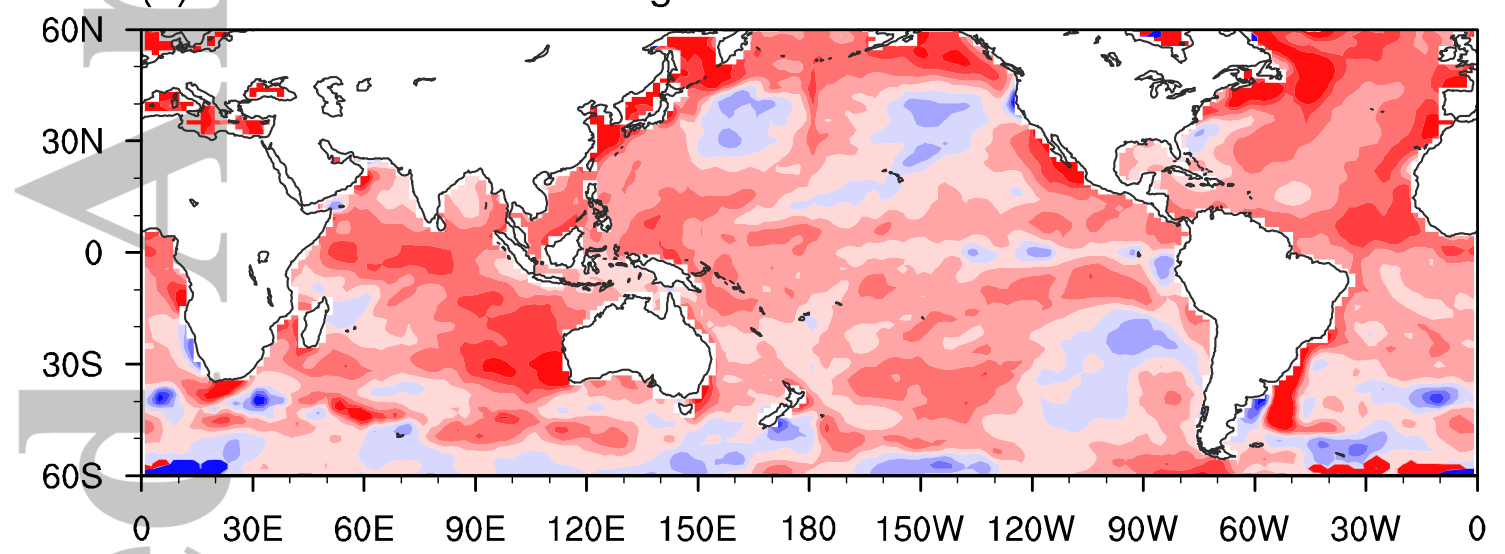

(c)MetUM-GOML2:summer SST change between PD and EP

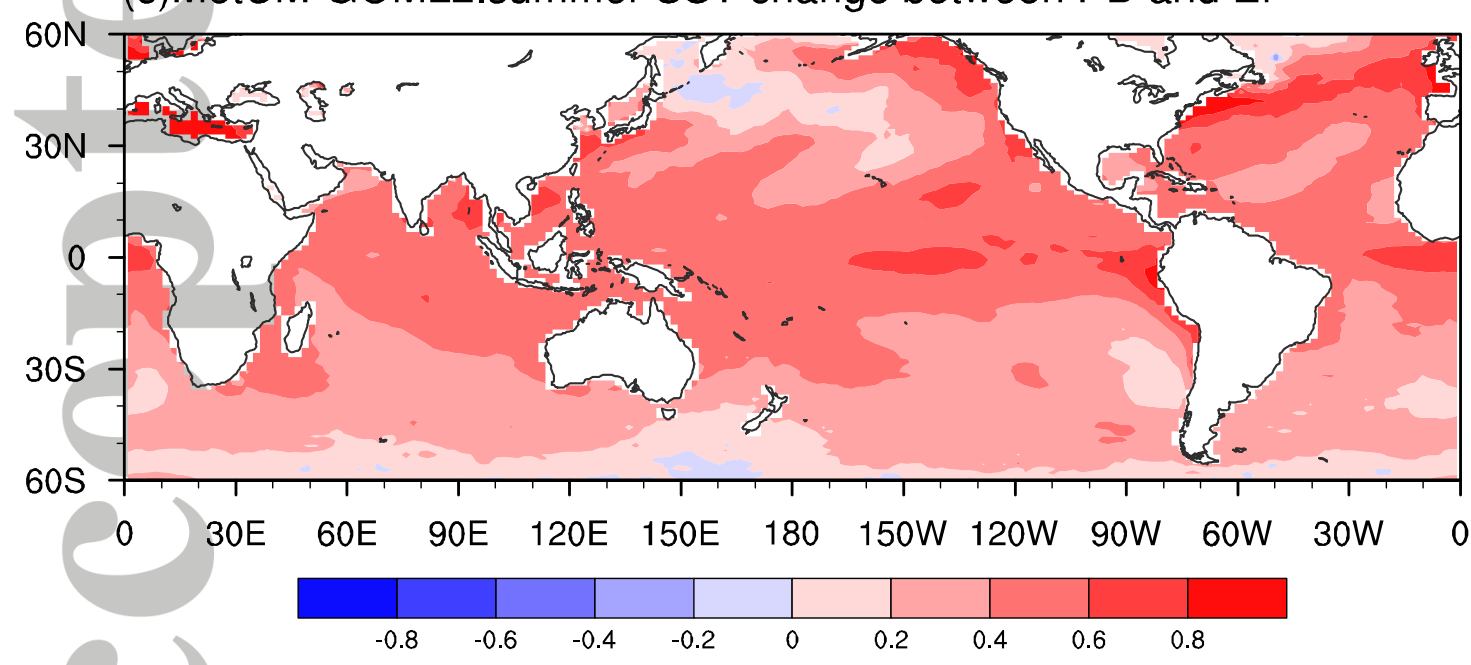

Figure 4. (a) Summer mean SST bias of MetUM-GOML2 simulation relative to HadISST for PD period. Summer mean SST difference between PD and EP in (b) Observations and (c) MetUM-GOML2. (units: ${ }^{\circ} \mathrm{C}$ ) 

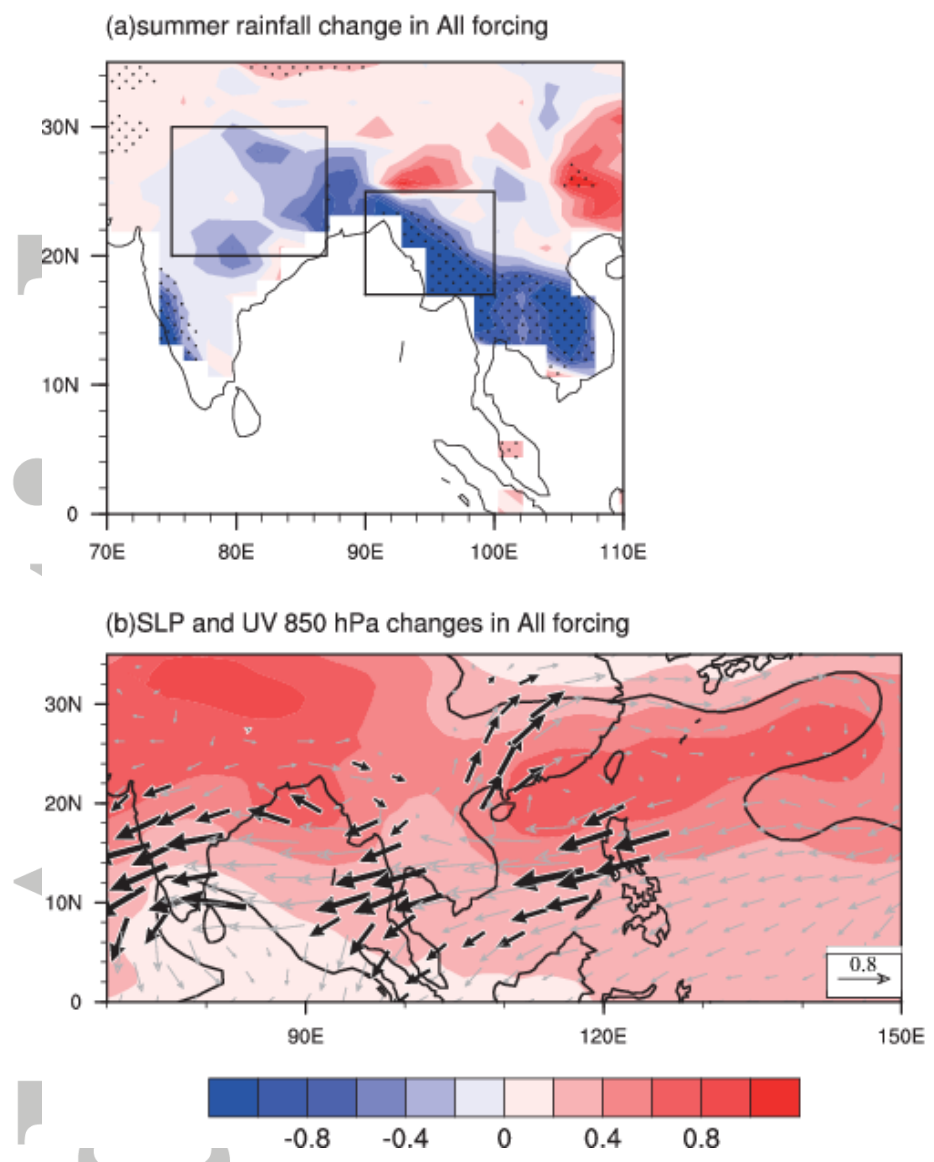

Figure 5. Spatial patterns of responses to All forcing. (a) precipitation (units: mm/day) (b) SLP (units: $\mathrm{hPa}$ ) and $850 \mathrm{hPa}$ wind (units: $\mathrm{m} / \mathrm{s}$ ) in summer. Box indicates selected region of the ISR and SEASR. Black dots in (a), black lines and black arrowheads in (b) indicate statistical significance at the $10 \%$ level using a two-tailed Student t-test. 
(a)GHG forcing

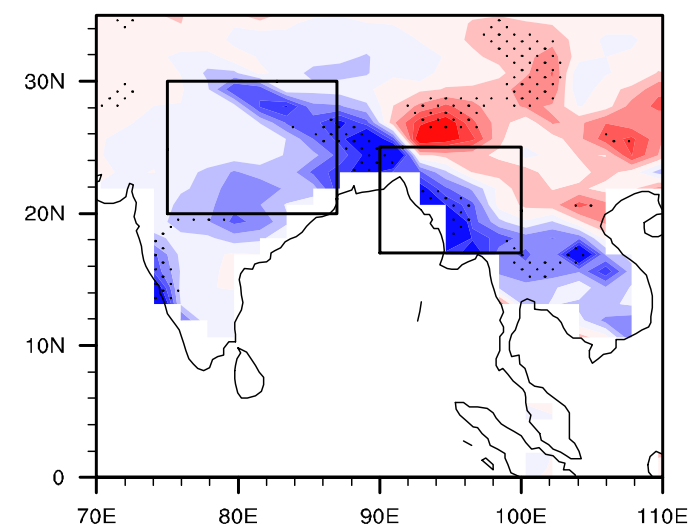

(b)AA forcing
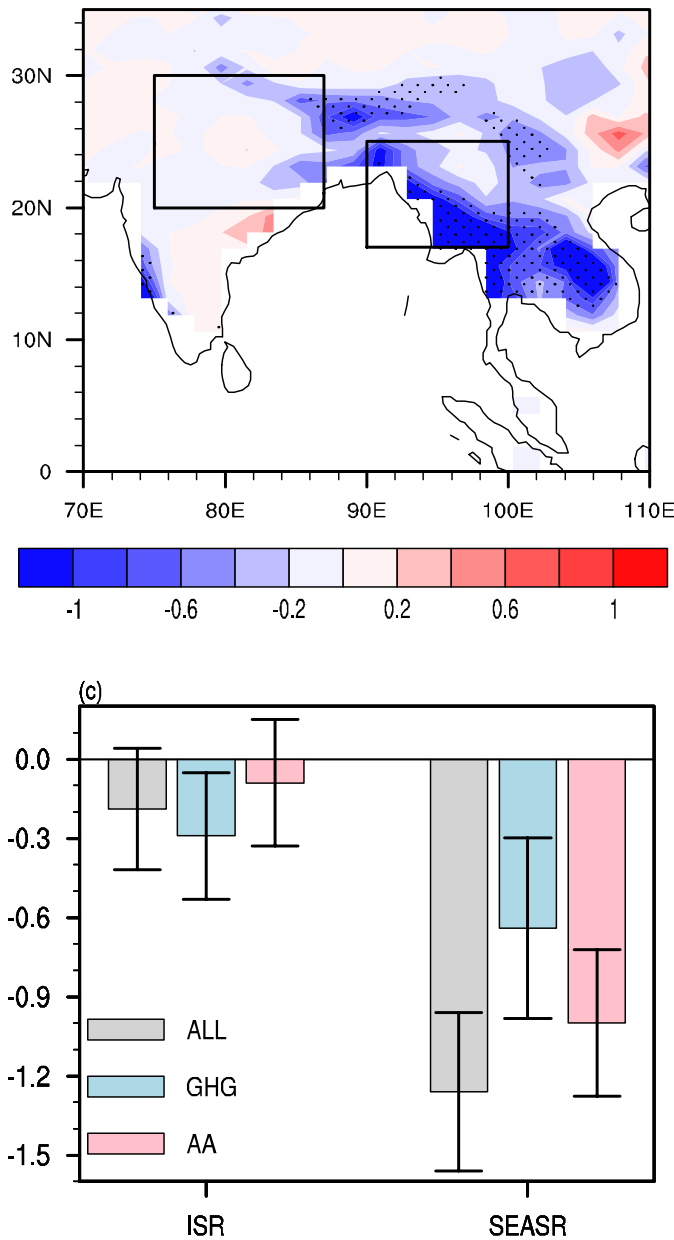

Figure 6. Spatial patterns of responses in summer rainfall to (a) GHG forcing and (b) AA forcing. Black dots indicate statistical significance at the $10 \%$ level using a two-tailed Student t-test. (c) Area averaged rainfall over selected region of the ISR and SEASR. Error bars indicate the standard error of difference of the variables. (units: $\mathrm{mm} / \mathrm{day}$ ) 

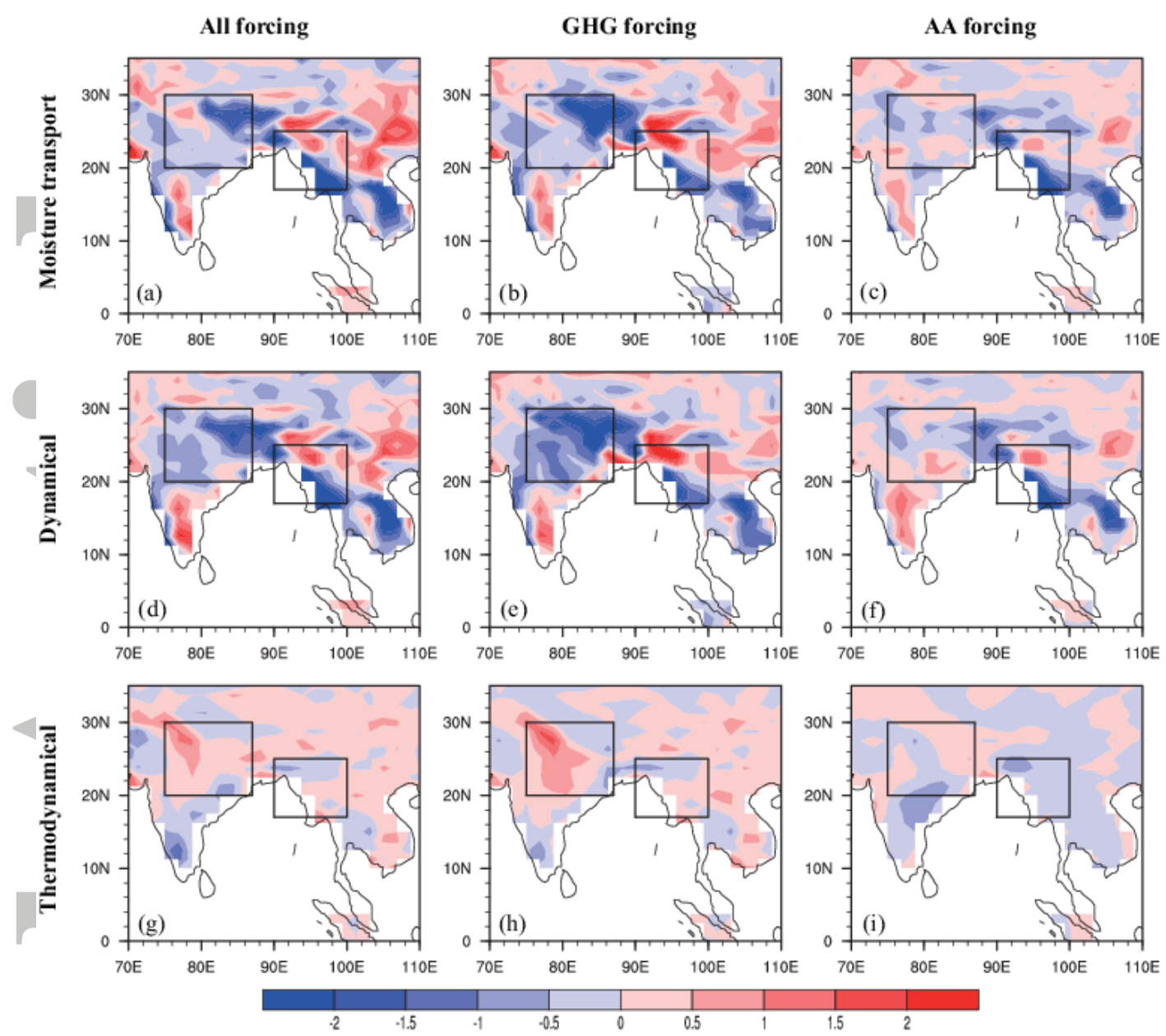

Figure 7. (a-c) differences of the vertically integrated moisture transport convergence between PD and EP experiments in summer for All Forcing, GHG forcing and AA forcing respectively. (d-f) same as (a-c) but the differences of dynamical effect. (g-i) same as (a-c) but the differences of thermodynamic effect. (units: $\mathrm{mm} /$ day) 

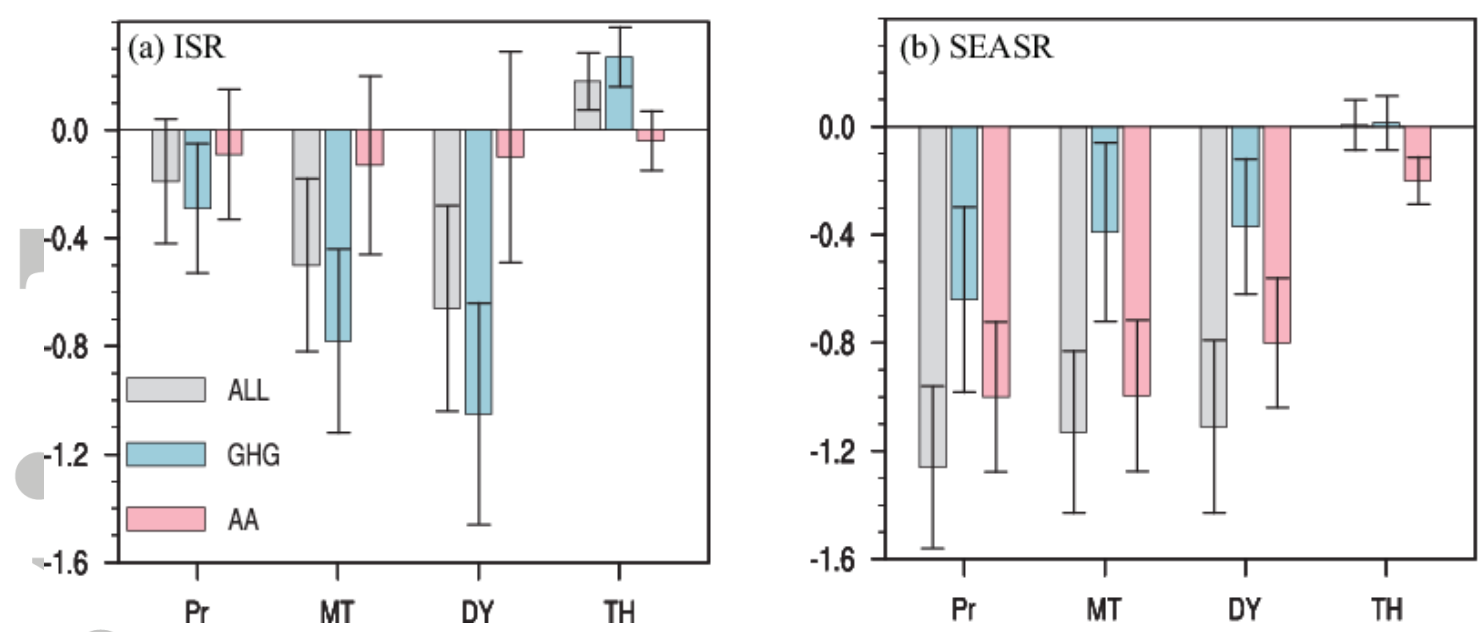

Figure 8. Area averaged precipitation (Pr), vertically integrated moisture transport convergence (MT), dynamic effect (DY) and thermodynamic effect (TH) in (a) over ISR region and (b) over SEASR region in response to All Forcing (gray), GHG forcing (green) and AA forcing (pink). Error bars indicate the standard error of difference of the variables. (units: $\mathrm{mm} /$ day) 
(a)SLP\&UV $850 \mathrm{hPa}$
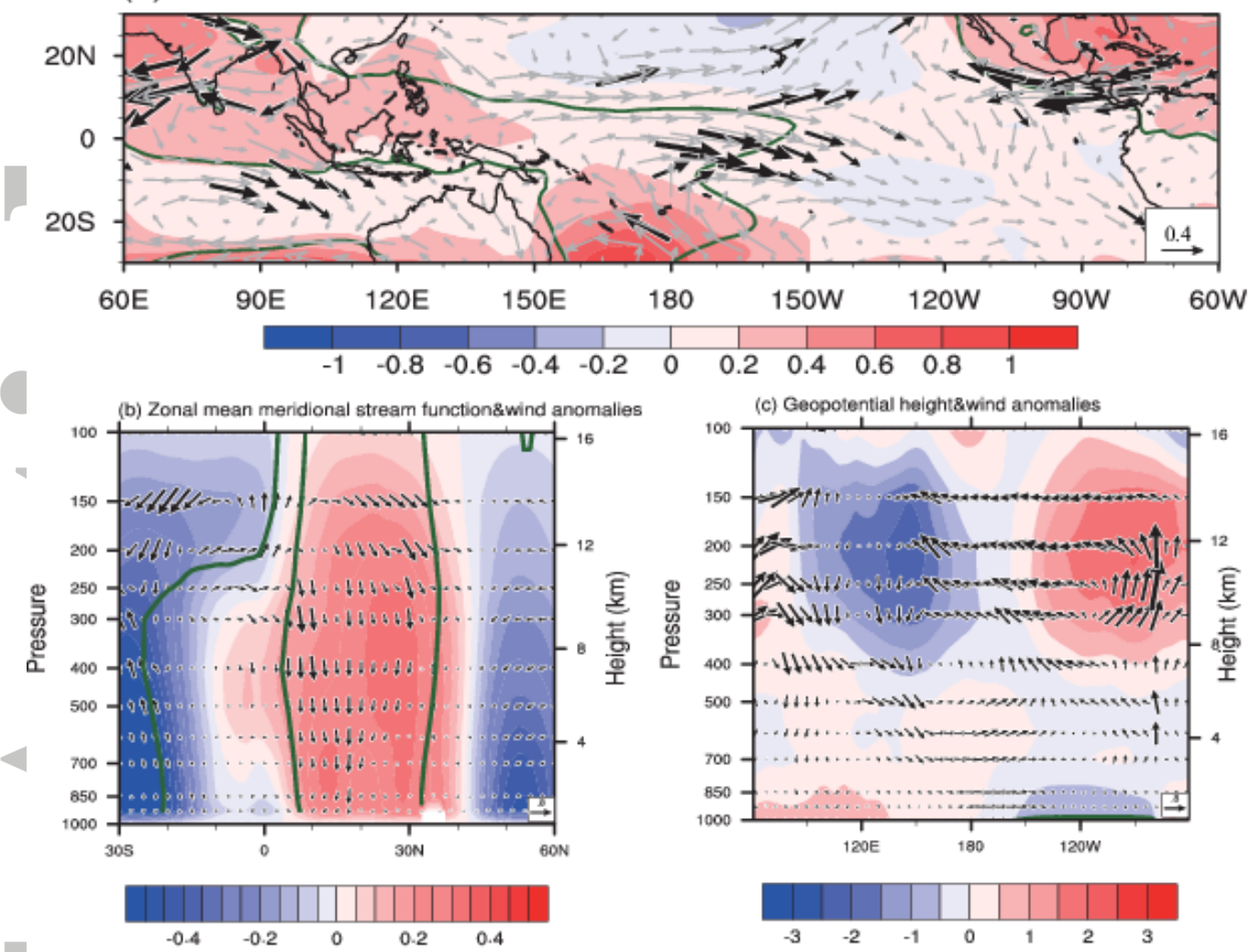

(d) Ts

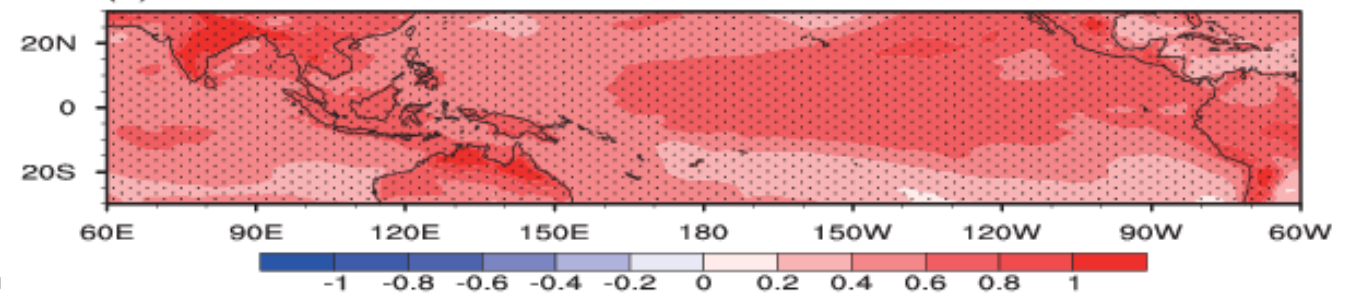

(e) net clear sky LW

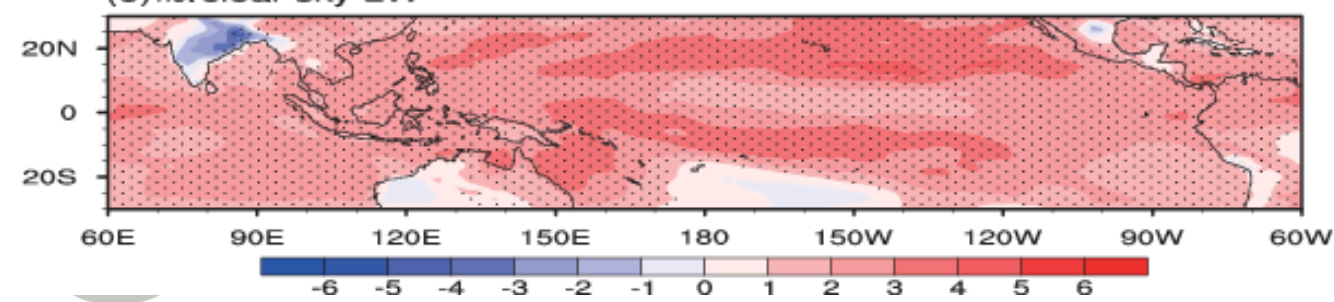

Figure 9. Spatial patterns of responses to GHG forcing in summer. (a) SLP (units: hPa) and $850 \mathrm{hPa}$ wind (units: $\mathrm{m} / \mathrm{s}$ ), (b) Zonal mean meridional stream function (units: $\mathrm{kg} / \mathrm{s} \times 10^{10}$ ) and wind anomalies (units: $\left.\mathrm{m} / \mathrm{s} \times 10^{-3}\right)$ averaged over sector $\left(60^{\circ} \mathrm{E}-100^{\circ} \mathrm{E}\right),(\mathrm{c})$ Geopotential height (units: $\mathrm{m}$ ) and wind anomalies (units: $\mathrm{m} / \mathrm{s} \times 10^{-3}$ ) averaged meridionally over sector $\left(10^{\circ} \mathrm{S}-10^{\circ} \mathrm{N}\right),(\mathrm{d})$ Surface temperature (Ts) (units: ${ }^{\circ} \mathrm{C}$ ), and (e) net clear sky LW (units: $\mathrm{W} \mathrm{m}^{-2}$, positive values mean download). Green lines, black dots and black arrowheads indicate statistical significance at the $10 \%$ level using a two-tailed Student t-test. 

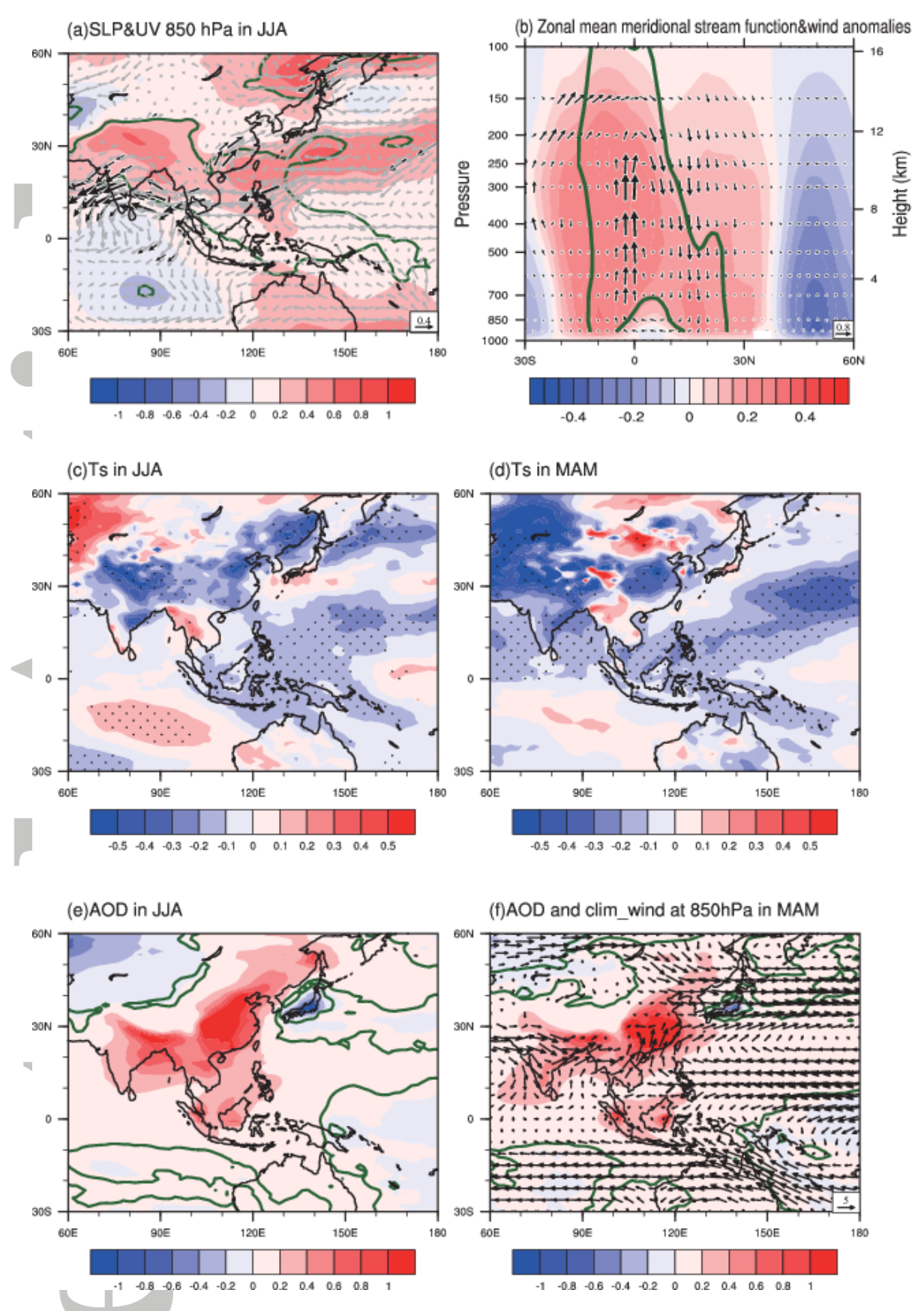

Figure 10. Spatial patterns of responses to AA forcing in summer. (a) SLP (units: hPa) and 850 hPa wind (units: $\mathrm{m} / \mathrm{s}$ ) and (b) Zonal mean meridional stream function (units: $\mathrm{kg} / \mathrm{s} \times 10^{10}$ ) and wind anomalies (units: $\left.\mathrm{m} / \mathrm{s} \times 10^{-3}\right)$ averaged over sector $\left(60^{\circ} \mathrm{E}-100^{\circ} \mathrm{E}\right)$. Surface temperature $(\mathrm{Ts})$ in (c) summer and (d) spring (units: ${ }^{\circ} \mathrm{C}$ ). (e) all aerosols AOD in summer. (f) all aerosols AOD and climate state of $850 \mathrm{hPa}$ horizontal wind (units: $\mathrm{m} / \mathrm{s}$ ). Black dots, green lines and black thick arrowheads indicate statistical significance at the $10 \%$ level using a two-tailed Student t-test. 

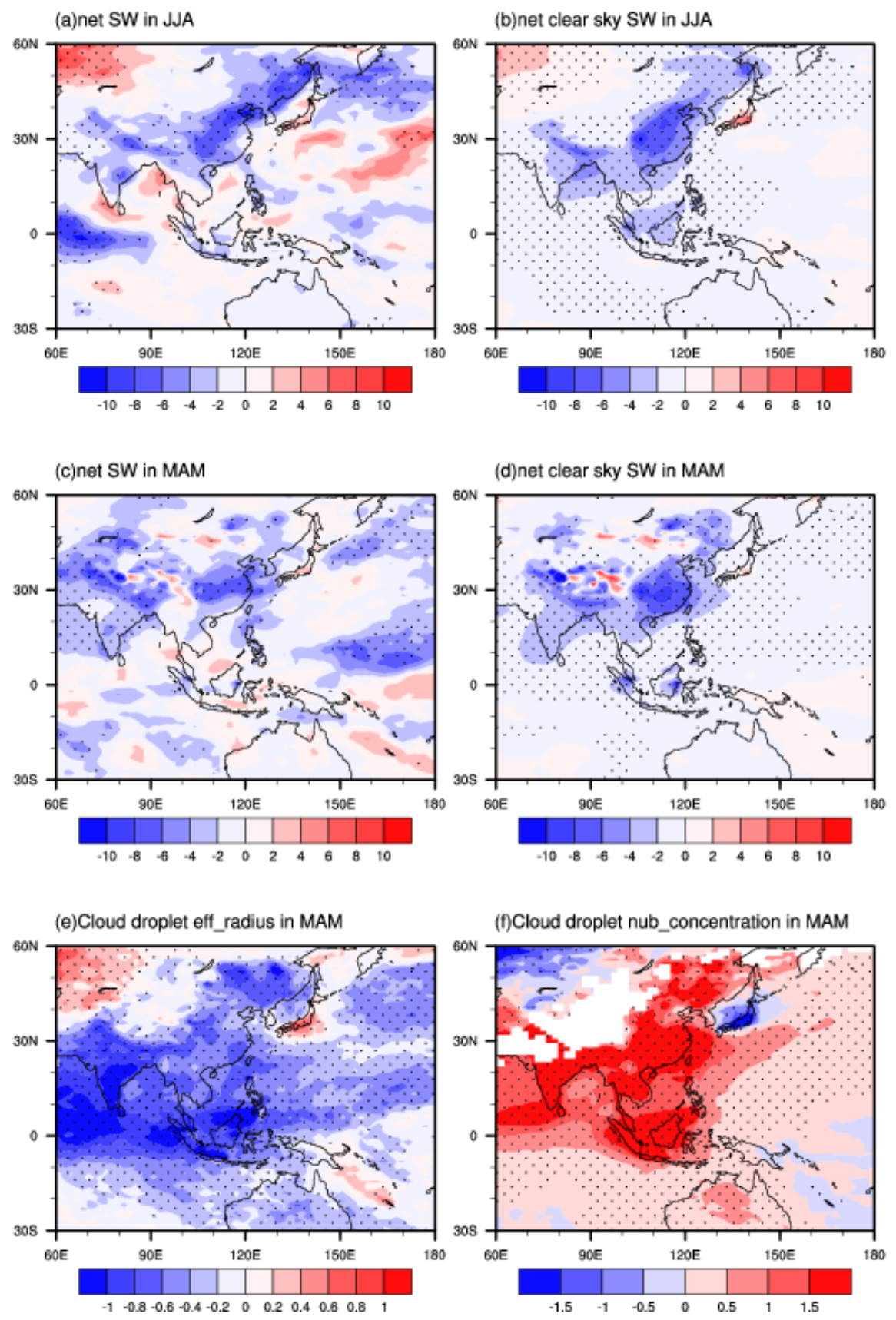

Figure 11. Spatial patterns of responses to AA forcing. (a) net surface SW and (b) net clear sky SW in summer (units: $\mathrm{W} \mathrm{m}^{-2}$, positive values mean download). (c-d) same as (a-b) but for spring. (e) cloud droplet effective radius (units: um) and (f) cloud droplet number concentration (units: $10^{10} \mathrm{~m}^{-2}$ ) in spring. Black dots indicate statistical significance at the $10 \%$ level using a two-tailed Student t-test. 

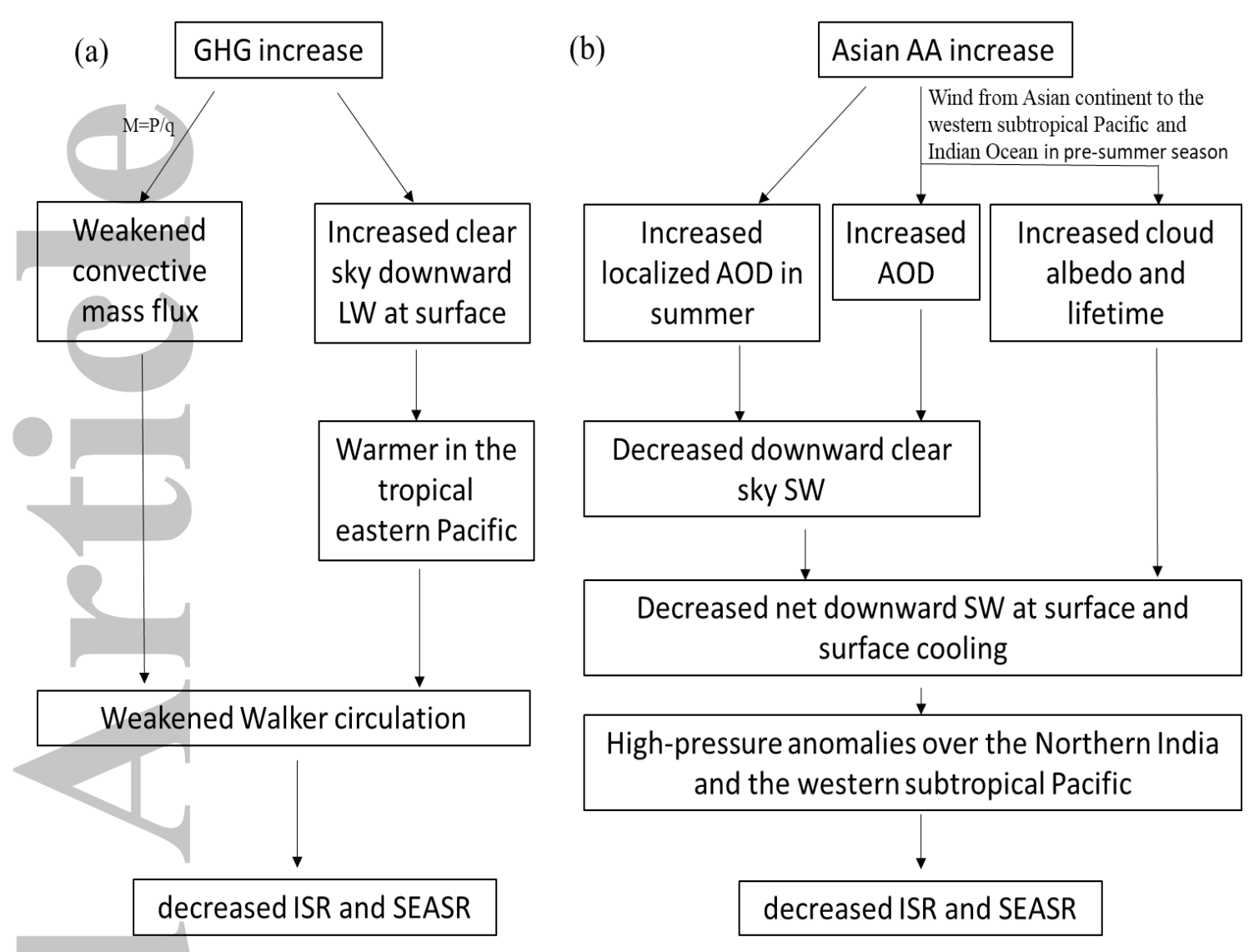

Figure 12. Schematic diagram illustrating the major processes of the responses in the ISR and SEASR to (a) GHG forcing and (b) AA forcing. 